\title{
A Novel Alternative Methods for Decalcification of Water Resources Using Green Agro-Ashes
}

\author{
Safaa El-Nahas ${ }^{1}{ }^{\mathbb{D}}$, Abdulrahem S. Arafat ${ }^{2}$, Hanan Salah El Din ${ }^{1}$, Abdulrahman G. Alhamzani ${ }^{3, * \mathbb{D}}$, \\ Mortaga M. Abou-Krisha ${ }^{1,3}$ and Hesham M. Alsoghier ${ }^{1}$ \\ 1 Chemistry Department, Faculty of Science, South Valley University, Qena 83523, Egypt; \\ Safaa33@yahoo.com (S.E.-N.); hanan.eldin@yahoo.com (H.S.E.D.); \\ mmaboukrisha@imamu.edu.sa (M.M.A.-K.); hgmohmed@gmail.com (H.M.A.) \\ 2 Red Sea Company for Drinking and Waste Water, Hurghada 84511, Egypt; abdoarafat46@yahoo.com \\ 3 Chemistry Department, College of Science, Imam Mohammad Ibn Saud Islamic University (IMSIU), \\ Riyadh 11623, Saudi Arabia \\ * Correspondence: agalhamzani@imamu.edu.sa
}

Citation: El-Nahas, S.; Arafat, A.S.; El Din, H.S.; Alhamzani, A.G.;

Abou-Krisha, M.M.; Alsoghier, H.M. A Novel Alternative Methods for Decalcification of Water Resources Using Green Agro-Ashes. Molecules 2021, 26, 6777. https://doi.org/ $10.3390 /$ molecules 26226777

Academic Editor: Carlo Santoro

Received: 13 October 2021

Accepted: 2 November 2021

Published: 10 November 2021

Publisher's Note: MDPI stays neutral with regard to jurisdictional claims in published maps and institutional affiliations.

Copyright: (C) 2021 by the authors. Licensee MDPI, Basel, Switzerland. This article is an open access article distributed under the terms and conditions of the Creative Commons Attribution (CC BY) license (https:// creativecommons.org/licenses/by/ $4.0 /)$.

\begin{abstract}
The strategic idea in this work was to increase $\mathrm{pH}$ values by employing natural alkali sources (i.e., $\mathrm{HCO}_{3}{ }^{-}$and $\mathrm{CO}_{3}{ }^{2-}$ ) from four tested agro-ashes as an alternative to chemicals (i.e., lime or soda ash). The considerable proportion of carbonates and bicarbonates in the investigated ash products had remarkable features, making them viable resources. All ash materials showed a significant ability for $\mathrm{Ca}$ ion elimination at high initial $\mathrm{Ca}$ ion concentrations. A slight quantity of ash $(10 \mathrm{~g} / \mathrm{L})$ was sufficient for usage on very hard water contents up to $3000 \mathrm{ppm}$. Finally, the tested agro-ash was free of cost. Furthermore, unlike other conventional precipitants, such as $\mathrm{NaOH}$, $\mathrm{Ca}(\mathrm{OH})_{2}, \mathrm{NaHCO}_{3}, \mathrm{Na}_{2} \mathrm{CO}_{3}$, and $\mathrm{CaO}$, they are cost effective and ecologically sustainable. There is no need to employ any additional chemicals or modify the agro-ash materials throughout the treatment process. The benefits of the manufactured ash were assessed using a SWOT analysis.
\end{abstract}

Keywords: hardness removal; agro-ash; agro-waste; removing calcium ions; SWOT analysis

\section{Introduction}

No living being can survive without water. Therefore, water is fundamental for human life. Water is essential in cultivation, cleaning, mining, and industrial usage in addition to drinking purposes [1]. Water scarcity, climate change, and pollution are the most essential environmental topics to be concerned about in the 21st century [2]. As water resources are limited, one of the biggest problems facing the world these days is the water crisis. Water scarcity arises when the demand for freshwater exceeds accessible water. Thus, great efforts are needed for better management of available water resources to reduce water shortages, and easy access to a fair amount of clean water is one of the main goals of the Sustainable Development Goals (i.e., Goal 6). Wastewater from the industrial sector is discharged by direct or indirect methods and easily pollute water supplies in the surrounding environment. Globally, approximately 300-400 million tons of pollutants (toxic sludge, heavy metals, organic waste, and solvents) are deposited every year into the surrounding environment via industrial plants [1]. Management of industrial water is a vital topic in sustainable development. Taking into account that, in accordance with a country's industrial progress, approximately $20 \%$ of the freshwater widely consumed is used for industrial purposes. In developing countries, this percentage falls to less than $10 \%$, while in developed countries it doubles. Internationally, this ratio is expected to increase as a result of the growing population and industrial development [3]. Improvement in water-use efficiency can minimize the expected gap between water demand and supply to approximately $40 \%$ in order to find a solution to water scarcity by 2030 . Notably, the growth in water demand is projected particularly for the production of energy and electricity via 
hydroelectricity. In addition, water employed in industrial processes is mainly used in cooling systems [4]. Challenges facing the water sector were highlighted as an important issue related to economic activities and water services. One of the widespread and costly problems in many industrial processes is scaling formation. The elimination of calcium ions from aqueous solutions is considered a rich area for study in industrial uses [5]. Hard water means there are high soluble amounts of $\mathrm{Ca}$ and $\mathrm{Mg}$ ions in the water supply. The presence of calcium ions in water or wastewater is the reason for numerous operational problems with extensive economic implications [6]. Continuous usage of hard water forms scale on the interior walls of domestic and industrial machinery. The augmentation of the scale formation leads to the blockage of pipes. Moreover, scales decrease the flux rate in pipes, decline heat transfer performance, in some cases cause malfunction of the equipment, and in the worst case leads to closure of the industrial unit $[7,8]$. Scales are precipitates of calcium ions as carbonate, phosphate, or sulphate, but they largely form as calcium carbonate $[8,9]$. Currently, the employment of evaporation technology has achieved great interest in the treatment of wastewater, as it can be utilized for extremely intense wastewater pollutants. Many evaporation systems, such as multistage flash (MSF), multiple effect evaporation (MEE), thermal vapor compression (TVC), and mechanical vapor recompression (MVR), are largely employed [10]. Among these techniques, MVR is more desirable because of its economical, energy-saving, easy operation, and low-temperature evaporation process. MVR has been broadly employed in various manufacturing industries such as the chemical of purification food, petrochemicals, wastewater purification, and desalination [10,11]. The water or wastewater used by the MVR technique should contain low concentrations of calcium and magnesium ions, below 100 ppm and 500 ppm, respectively. A decline in scale ions has become essential as an earlier step in such evaporation techniques as a result of low thermal conductivity and a reduction in heat transfer in the heater or boiler of scales [11]. Therefore, the membrane fouling efficiency used for the discharged wastewater of flue gas desulfurization (FGD) employed in thermal power plants (such as wet scrubber technologies) is negatively affected by high levels of hardness ions such as $\mathrm{Ca}$ and $\mathrm{Mg}$. Hence, eliminating $\mathrm{Ca}$ and $\mathrm{Mg}$ ions from the FGD wastewater treatment are essential steps for facilitating the ordinary operation of the membrane system [12]. Most of the industrial sector attempts to precipitate $\mathrm{Ca}$ ions from solutions such as $\mathrm{CaCO}_{3}$. This can be accomplished by increasing the $\mathrm{pH}$ with the addition of a base (e.g., $\mathrm{NaOH}$ or $\mathrm{Ca}(\mathrm{OH})_{2}$ ) as a conventional remedy for hardness problems in the occurrence of sand granules [9]. Several approaches have been published for the removal of ions causing scales (i.e., $\mathrm{Ca}$ and $\mathrm{Mg}$ ions) using different methods such as $\mathrm{CaO} / \mathrm{Na}_{2} \mathrm{CO}_{3}$, precipitation by oxalic acid and phenoxy acetic acid [11], selective nanocomposite electrosorption electrode [13], ion exchange resins (the alkyl phenoxy acetic acid derivatives) [11], injection of $\mathrm{CO}_{2}$ gas [14], microbial carbonate precipitation process (MCP) [15], phosphosilicate glass [5], wheat straw ash (WSA) and rice husk ash (RHA) [16], brine pre-treatment waste of soda ash plant such as an alkali source and $\mathrm{CO}_{2}$ [17], and synthetic zeolite [18]. In the scope of the present circumstances, it is important to achieve sustainable development for future generations, utilizing the principles and concepts of green chemistry [1]. It is time to change our approaches by using eco-friendly applications to reduce the quantity of waste (Goal 12 of the SDGs). Agricultural wastes are undesirable substances and are freely available. By 2030, the recycling perspective of waste materials assessed in tons should be increased. The environmentally sound management of chemical and hazardous waste for healthy lifestyles via the use of clean water, air, safe food, and a sustainable ecosystem helps to reduce consumption of primary resources [19]. In 2013, burned biomass ash waste reached 480 million tons and will increase for years throughout the consumption of biomass as fuel [20]. The current environmental criteria emphasize the need to promote recycling processes to convert unattractive waste into usable materials [21]. This work took advantage of the naturally present inorganic minerals in biomass for reuse as alkali sources to increase the $\mathrm{pH}$ value of aquatic solutions. The carbonate and bicarbonate content of ash materials have many advantages and benefits. They are readily available, inexpensive as 
waste, and have basic nature in water. They are suitable precipitants for removing calcium ions from any aqueous solutions without any addition of a base (i.e., $\mathrm{NaOH}, \mathrm{Ca}(\mathrm{OH})_{2}$, or $\mathrm{KOH})$. Thus, the ash material can be easily used as an alternative to lime/soda ash or $\mathrm{Ca}(\mathrm{OH})_{2}$. Ash materials are not recognized as toxic substances, and they are a product from edible plants. Thus, the goal of this study was the green removal of calcium ions from water supplies using different agro-ash materials as an economic source of natural minerals.

\section{Experimental}

\subsection{Collection of Raw Materials for Ash}

Potato peel (Solanum tuberosum), banana peel (Musa), eggplant peel (Solanum melongena), and the stem of mint (Mentha) were the domestic wastes. First, they were washed thoroughly with deionized water to remove dust, color, and other impurities. Then, they were cut separately into small pieces. After washing, they were dried in an electric oven at $80^{\circ} \mathrm{C}$ for $4 \mathrm{~h}$ until they reached a stable mass. The dried samples were crushed to make a homogenous phase. The dried wastes were burned in a muffle furnace at $500{ }^{\circ} \mathrm{C}$ for $6 \mathrm{~h}$. The resulting ashes were milled, sieved, and stored in desiccators prior to use in benchscale experiments or for analysis of their physical characterization. Figure 1 represents the method used for the preparation, and the obtained ashes yields were approximately 10.5\%, $25 \%, 11.3 \%$, and $13.7 \%$ of the waste dry matter for potato peel, banana peel, eggplant peel, and mint stem, respectively. The amount of ash yield was comparable to data published by others [16].

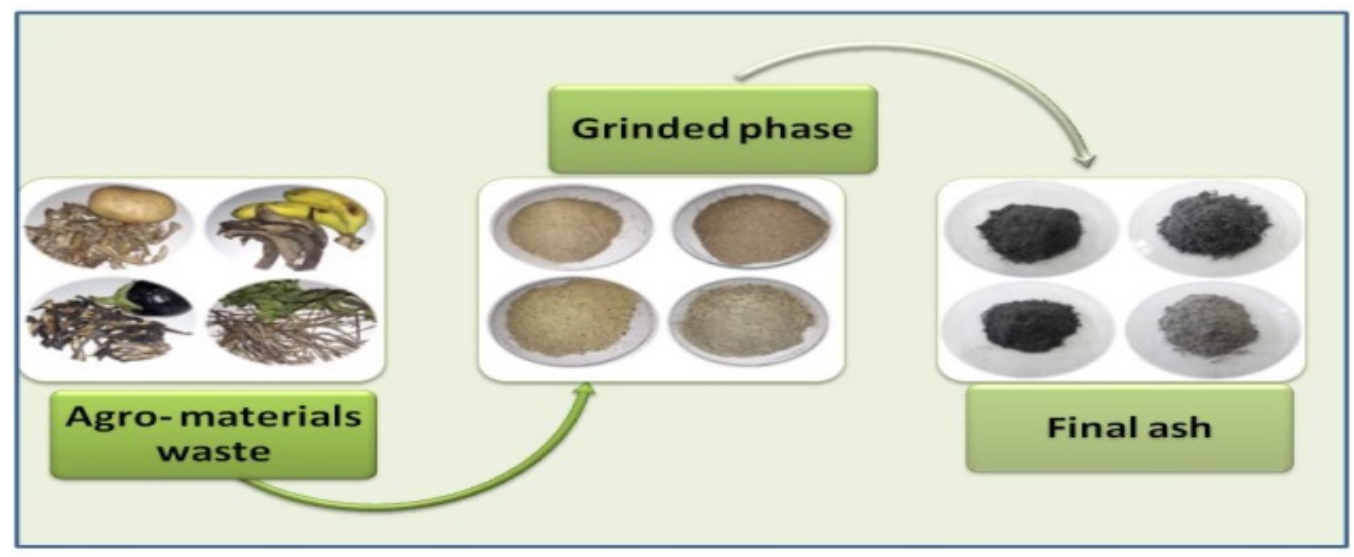

Figure 1. Method for preparation of agro-ash.

\subsection{Characteristics of Fly Ash Samples}

The prepared ash samples (i.e., Po-ash is Potato peel Ash, BA-ash is Banana peel Ash, Eg-Ash is Eggplant ash, and Min-Ash is Mint stem ash) were characterized by various spectroscopic techniques, such as FTIR (Fourier transform infrared), and measurements were conducted using a (Nicolet) Magna-FTIR-560 (USA) with the KBr technique and powder X-ray diffraction analysis (XRD) of the ashes using a Brucker Axs-D8 Advance Diffractometer (Belgium) at ambient temperatures in the $2 \Theta$ range between 10 and $70^{\circ}$. The morphology and elemental analyses of the ash samples were characterized using an EDX (Model FEI INSPECT S50) operating at $20 \mathrm{kV}$. The desired $\mathrm{pH}$ values of the solutions were measured using a precision $\mathrm{pH}$ meter (Model PHS-3C).

\subsection{Chemicals and Materials}

The stock solution of $\mathrm{Ca}$ (II) was $4000 \mathrm{mg} / \mathrm{L}$. $\mathrm{HCl}(0.5 \mathrm{M})$ or $\mathrm{NaOH}(0.5 \mathrm{M})$ solutions were used. Chemical precipitants, such as $\mathrm{NaOH}, \mathrm{Ca}(\mathrm{OH})_{2}, \mathrm{NaHCO}_{3}, \mathrm{Na}_{2} \mathrm{CO}_{3}$, and $\mathrm{CaO}$, were purchased from (Sigma-Aldrich (USA), Fluka (UK), and Merck (Germany)) and used directly. 


\subsection{Hardness Removal Experiment}

The examined parameters for the removal efficiency of calcium ions by tested ashmaterials were the individual effects of the initial concentrations (1000-4000 ppm), pH (2-10), contact time (1-180 min), and adsorbent dosage (1-14 g/L), while the operating temperature was fixed at $25^{\circ} \mathrm{C}$. For each analysis, $0.5 \mathrm{~g}$ of ash $/ 50 \mathrm{~mL}$ of Ca (II) solution (1000 ppm) was put into a $250 \mathrm{~mL}$ flask and mixed. The shaker speed was set to $200 \mathrm{rpm}$ for stirring for $1 \mathrm{~h}$ at room temperature. After shaking, the residue ash was separated from the solution by filtration, and the final $\mathrm{Ca}^{2+}$ concentration was determined according to the standard method in the 23rd Edition, no: 3500-Ca B [22]. Moreover, $\mathrm{pH}$, TDS, and conductivity were measured for $C_{o}$ and $C_{e}$ of $C a$ ions. The percentage of $C a$ ion removal was calculated according to Equation (1).

$$
\% \text { Removal }=\frac{\left(C_{o}-C_{e}\right)}{C_{o}} \times 100
$$

where $C_{o}$ and $C_{e}$ are the initial and the final $C$ a ion concentrations at equilibrium $\left(\mathrm{mg} \cdot \mathrm{L}^{-1}\right)$, respectively.

\subsection{Studying Other Chemical Precipitations Compared with Agro-Ash}

Several laboratory examinations were carried out to compare various conventional methods. In this section, five common chemical precipitants were utilized, such as $\mathrm{NaOH}$, $\mathrm{Ca}(\mathrm{OH})_{2}, \mathrm{NaHCO}_{3}, \mathrm{Na}_{2} \mathrm{CO}_{3}$, and $\mathrm{CaO}$ as well as the two mixtures of $\mathrm{CaO}$ and $\mathrm{Na}_{2} \mathrm{CO}_{3}$ and $\mathrm{Ca}(\mathrm{OH})_{2}$ and $\mathrm{Na}_{2} \mathrm{CO}_{3}$ for the elimination of $\mathrm{Ca}$ ions from solutions compared with tested ago-ashes.

\section{Results and Discussion}

\subsection{XRD Analysis of Ash Materials}

The XRD results confirmed the exact mineral composition of the prepared agro-ashes. The data from the XRD patterns for the tested agro-ashes are illustrated in Figure 2 and Table 1. The major constituent in all of the ash samples was sylvite $(\mathrm{KCl})$. Individually, Po-ash constitutions comprised seven minerals: nahcolite $\left(\mathrm{NaHCO}_{3}\right)$, kalicinite $\left(\mathrm{KHCO}_{3}\right)$, langbeinite $\left(\mathrm{K}_{2} \mathrm{Mg}_{2}\left(\mathrm{SO}_{4}\right)_{3}\right)$, bradleyite $\left(\mathrm{Na}_{3} \mathrm{Mg}\left(\mathrm{PO}_{4}\right) \mathrm{CO}_{3}\right)$, scawtite $\left(\mathrm{Ca}_{7}\left(\mathrm{Si}_{6} \mathrm{O}_{18}\right)\left(\mathrm{CO}_{3}\right) \mathrm{H}_{2} \mathrm{O}\right)$, sylvite $(\mathrm{KCl})$, and halite $(\mathrm{NaCl})$. While the composition of the Eg-ash observed had only five constituents: kalicinite $\left(\mathrm{KHCO}_{3}\right)$, langbeinite $\left(\mathrm{K}_{2} \mathrm{Mg}_{2}\left(\mathrm{SO}_{4}\right)_{3}\right)$, bradleyite $\left(\mathrm{Na}_{3} \mathrm{Mg}\left(\mathrm{PO}_{4}\right) \mathrm{CO}_{3}\right)$, nahcolite $\left(\mathrm{NaHCO}_{3}\right)$, and sylvite $(\mathrm{KCl})$. Min-ash had four constitutions: nahcolite $\left(\mathrm{NaHCO}_{3}\right)$, langbeinite $\left(\mathrm{K}_{2} \mathrm{Mg}_{2}\left(\mathrm{SO}_{4}\right)_{3}\right)$, calcite $\left(\mathrm{CaCO}_{3}\right)$, and sylvite $(\mathrm{KCl})$. BA-ash showed four compositions: scawtite $\left(\mathrm{Ca}_{7}\left(\mathrm{Si}_{6} \mathrm{O}_{18}\right)\left(\mathrm{CO}_{3}\right) \mathrm{H}_{2} \mathrm{O}\right)$, spurrite $\left(\mathrm{Ca}_{5}\left(\mathrm{SiO}_{4}\right)_{2} \mathrm{CO}_{3}\right)$, sylvite $(\mathrm{KCl})$, and halite $(\mathrm{NaCl})$. Calcium silicates were observed in other types of agriculture ash materials derived from wood [23,24]. The revealed data show most ash materials had major contents of $\mathrm{KCl}$ compared to $\mathrm{NaCl}$ as observed by another researcher [25]. Furthermore, many agricultural ash materials mainly contain multiple silicate compounds and chlorides, oxides, carbonates, sulphates, and phosphates for common metal ions such as $\mathrm{Ca}, \mathrm{K}, \mathrm{Mg}$, and $\mathrm{Na}[26,27]$. We can conclude from the XRD results that all tested ashes varied in the amount of carbonate and bicarbonate; in addition to $\mathrm{NaHCO}_{3}$ and $\mathrm{KHCO}_{3}$, Po-ash, BA-ash, and Egash contained other types of carbonates such as $\mathrm{Na}_{3} \mathrm{Mg}\left(\mathrm{PO}_{4}\right) \mathrm{CO}_{3}, \mathrm{Ca}_{7}\left(\mathrm{Si}_{6} \mathrm{O}_{18}\right)\left(\mathrm{CO}_{3}\right)\left(\mathrm{H}_{2} \mathrm{O}\right)_{2}$, and $\mathrm{Ca}_{5}\left(\mathrm{SiO}_{4}\right)_{2} \mathrm{CO}_{3}$. 

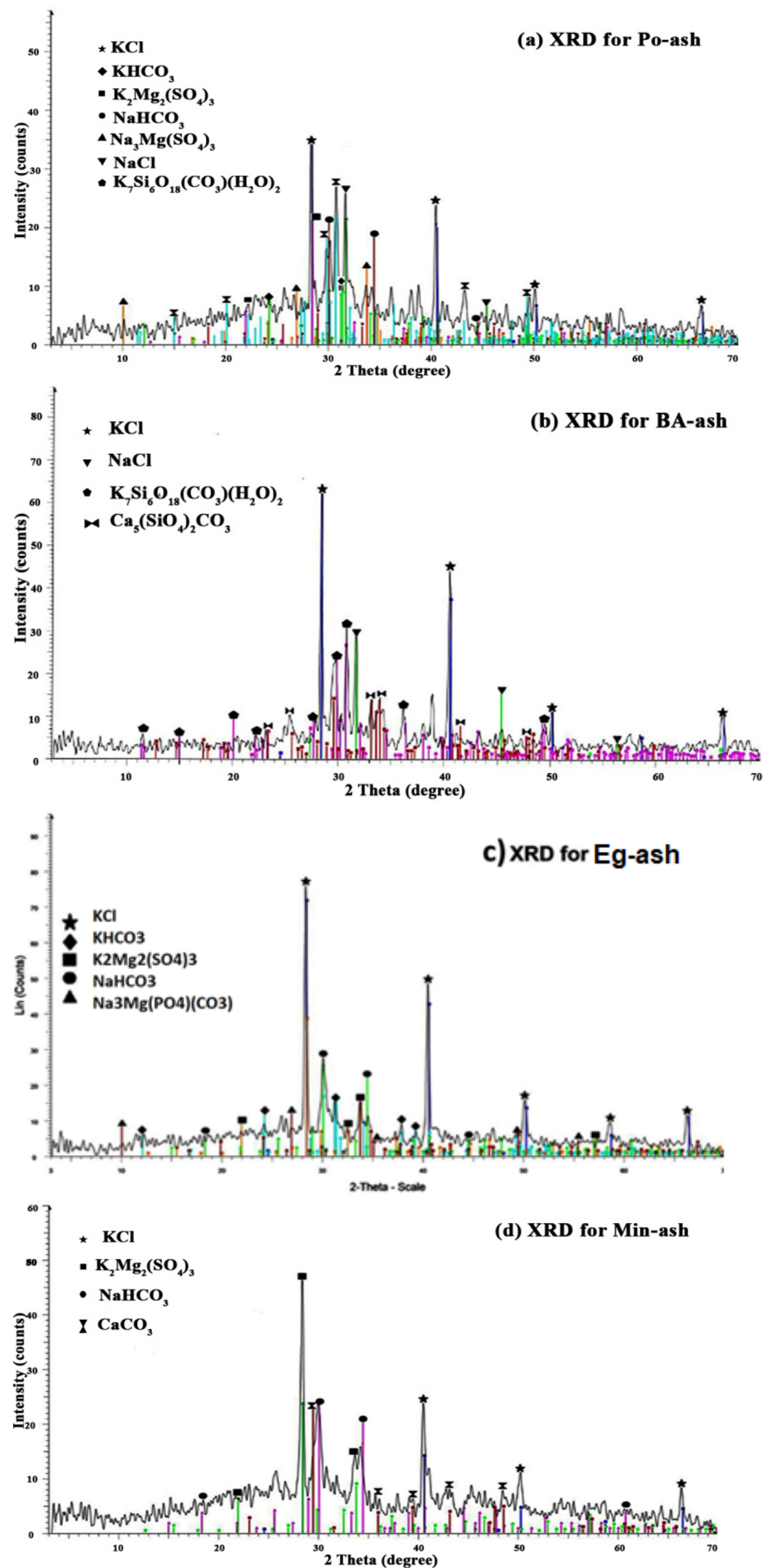

Figure 2. The XRD patterns for the characteristics of the agro-ash compositions: (a) Po-ash, potato peel ash; (b) BA-ash, banana peel ash; (c) Eg-ash, eggplant peel ash; (d) Min-ash, mint stem ash materials. 
Table 1. XRD analysis of the constitutions of the tested agro-ashes, (Po-ash is Potato peel Ash, BA-ash is Banana peel Ash, Eg-Ash is Eggplant ash, and Min-Ash is Mint stem ash).

\begin{tabular}{|c|c|c|c|c|c|c|}
\hline \multirow{2}{*}{$\begin{array}{l}\text { Minerals } \\
\text { Phase }\end{array}$} & \multirow{2}{*}{$\begin{array}{l}\text { JCPDS } \\
\text { Card }\end{array}$} & \multirow{2}{*}{$\begin{array}{l}\text { Chemical } \\
\text { Structure }\end{array}$} & \multicolumn{4}{|c|}{ Compositions of Agro-Ash Samples \% } \\
\hline & & & Po-ash & BA-ash & Eg-ash & Min-ash \\
\hline Sylvite, syn & $73-0380(\mathrm{C})$ & $\mathrm{KCl}$ & 6.0 & 15.5 & 11.5 & 7.4 \\
\hline Kalicinite & 70-1167 ((D) & $\mathrm{KHCO}_{3}$ & 11.7 & - & 19.8 & - \\
\hline Langbeinite & $72-1206(C)$ & $\mathrm{K}_{2} \mathrm{Mg}_{2}(\mathrm{SO} 4)_{3}$ & 16.0 & - & 27.4 & 33.2 \\
\hline Nahcolite & $21-1119$ (D) & $\mathrm{NaHCO}_{3}$ & 22.3 & - & 24.2 & 45.2 \\
\hline Bradleyite & $22-0478$ (I) & $\mathrm{Na}_{3} \mathrm{Mg}\left(\mathrm{PO}_{4}\right) \mathrm{CO}_{3}$ & 1.0 & - & 17.1 & - \\
\hline Halite, syn & $05-0628(*)$ & $\mathrm{NaCl}$ & 5.1 & 9.8 & - & - \\
\hline Scawtite & $81-1918(C)$ & $\mathrm{Ca}_{7}\left(\mathrm{Si}_{6} \mathrm{O}_{18}\right)\left(\mathrm{CO}_{3}\right)\left(\mathrm{H}_{2} \mathrm{O}\right)_{2}$ & 37.9 & 43.5 & - & - \\
\hline Spurrite & $13-0496$ (I) & $\mathrm{Ca}_{5}\left(\mathrm{SiO}_{4}\right) 2 \mathrm{CO}_{3}$ & - & 31.3 & - & - \\
\hline Calcite & $72-1652(C)$ & $\mathrm{CaCO}_{3}$ & - & - & - & 14.1 \\
\hline
\end{tabular}

\subsection{SEM-EDX Analysis of Ash Materials}

EDX analysis provided the elemental composition and constituent of the ashes as demonstrated in Figure 3. Noticeable variations in the major elements for the tested ash samples are illustrated in Table 2. High potassium contents were observed in all studied ash samples following the order BA-ash $>$ Min-ash $>$ Po-ash $>$ Eg-ash. While Na showed minor levels compared to K contents as observed in [25]. Po-ash and Eg-ash had small concentrations of calcium compared to BA-ash and Min-ash. However, the tested ashes showed that the carbon content varied from $11-25 \%$ in the following order: Eg-ash $>$ Po-ash $>$ Min-ash > BA-ash. In fact, $\mathrm{C}$ and $\mathrm{N}$ are usually oxidized during ignition and distorted to a gaseous component, but the amount of $C$ was still present in ash in indefinite amounts due to the fact of incomplete burning [28]. The presence of other elements, such as $\mathrm{Mg}, \mathrm{P}, \mathrm{S}, \mathrm{Cl}$, and $\mathrm{Si}$, was tolerable, as the ashes resulted from plant sources. In addition, the oxygen content varied from $36.9 \%$ to $69.6 \%$. The EDX analysis was compatible with XRD data for the existing elements in the ash compositions and their mineral phases. Ash reactivity and its elemental distribution were strongly impacted by the biomass structure [29]. Understanding the exact chemical composition of produced ash materials will be helpful in developing the reactivity of agriculture biomass as low-priced materials for water treatment.

Table 2. Elemental analysis (EDX) of the tested ash materials.

\begin{tabular}{|c|c|c|c|c|}
\hline \multirow{2}{*}{ Elements Composition } & \multicolumn{4}{|c|}{ Weight \% } \\
\hline & Po-ash & BA-ash & Eg-ash & Min-ash \\
\hline $\mathrm{C}$ & 22.44 & 11.26 & 25.72 & 14.49 \\
\hline $\mathrm{Na}$ & 0.27 & nd * & 0.2 & 0.96 \\
\hline $\mathrm{Mg}$ & 0.36 & 1.38 & 0.19 & 1.28 \\
\hline $\mathrm{Al}$ & 0.18 & nd * & nd * & 0.33 \\
\hline $\mathrm{Si}$ & 0.34 & 3.87 & nd * & 0.71 \\
\hline $\mathrm{P}$ & 0.44 & 0.91 & 0.19 & 1.38 \\
\hline S & 0.24 & 0.53 & 0.05 & 0.69 \\
\hline $\mathrm{Cl}$ & 1.3 & 5.7 & 1.32 & 6.05 \\
\hline K & 10.23 & 29.83 & 2.73 & 20.22 \\
\hline $\mathrm{Ca}$ & 0.27 & 2.25 & nd * & 4.03 \\
\hline $\mathrm{Fe}$ & nd & nd * & nd * & 0.35 \\
\hline $\mathrm{O}$ & 63.9 & 44.28 & 69.6 & 49.52 \\
\hline Total & 100 & 100 & 100 & 100 \\
\hline
\end{tabular}

* Not detected. 

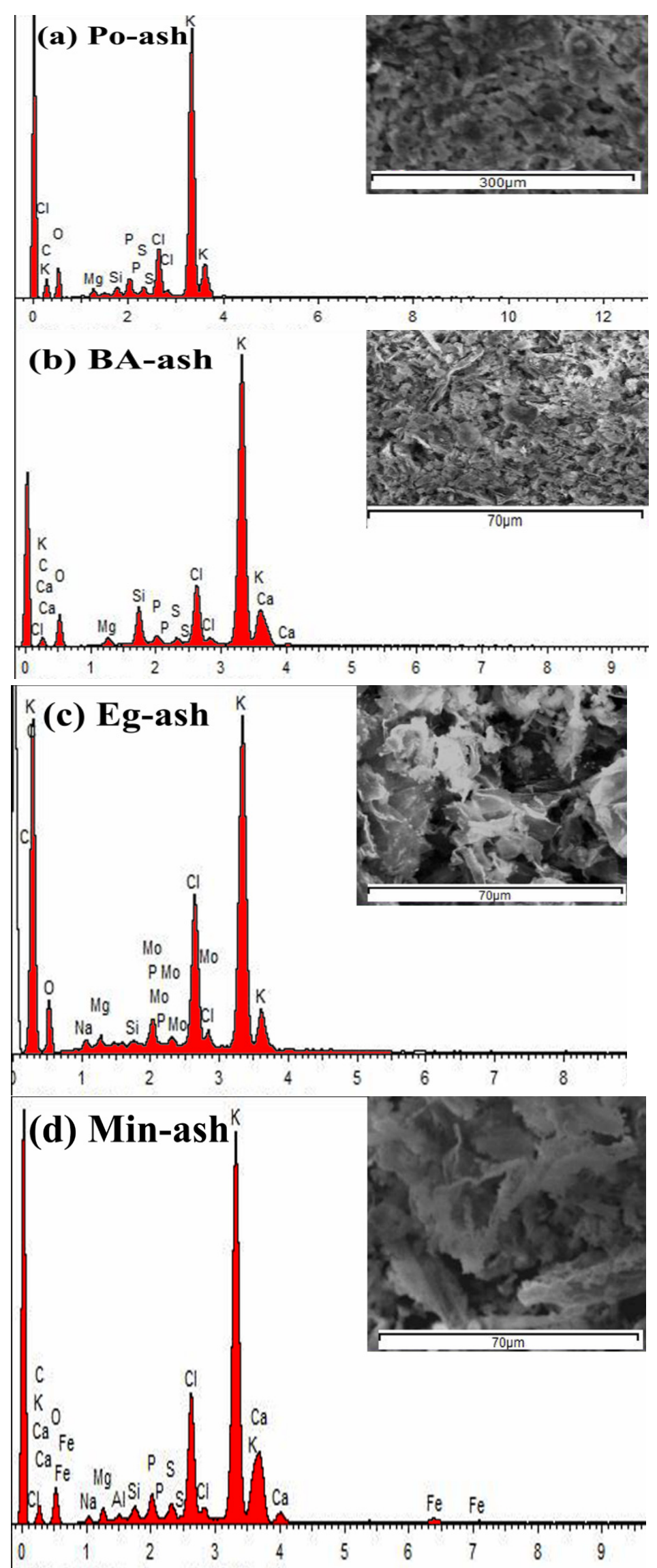

Figure 3. EDX-SEM analyses for (a) Po-ash; (b) BA-ash; (c) Eg-ash; (d) Min-ash materials. 
SEM images provide additional details regarding surface information of the tested materials at extremely high magnifications. The structures of the tested ash materials, as shown in the SEM photos, displayed a heterogeneous texture, and the particles had an irregular shape with crevices-like structure similar to others [30-33].

\subsection{FTIR Analysis}

FTIR (Fourier transform infrared spectroscopy) is a sensitive technique for recognizing active functional groups of compounds to identify the composition of organic or inorganic materials [34]. Table 3 signifies the distinct functional forms in the tested raw and ash materials. Agricultural waste materials usually include some essential components such as cellulose, hemicelluloses, lignin, lipids, proteins, simple sugars, water hydrocarbon, and starch [35]. The obtained spectra in Figure 4a exhibited various absorption bands for tested raw agriculture waste, indicating the complicated nature of the examined agriculture wastes. The FTIR spectra showed a broad band at approximately $3401 \mathrm{~cm}^{-1}$, representing bonded -OH groups [33,36]. While the band observed at approximately $2915 \mathrm{~cm}^{-1}$ could be assigned to the stretching $\mathrm{C}-\mathrm{H}$ bond of the $\mathrm{CH}_{2}$ group [33,37-39]. Furthermore, the bands at approximately $1749 \mathrm{~cm}^{-1}$ were assigned to the carboxyl groups (-COOH) of the peels' structure $[33,37,38]$. Moreover, the band at approximately 1064 corresponded to the stretching vibration of Si-O and Si-O-Si [33,36]. Furthermore, the band at $1639 \mathrm{~cm}^{-1}$ was assigned to the water bending vibration of the $\mathrm{H}-\mathrm{O}-\mathrm{H}$ bond $[39,40]$. It seems that these types of functional groups are similar to other waste materials reported in [37,38,41,42]. The spectra of agro-ash materials are illustrated in Figure $4 \mathrm{~b}$, and the bands of agricultural waste at approximately 3401 and $2915 \mathrm{~cm}^{-1}$ completely disappeared in the agro-ash spectra. However, new peaks appeared at approximately 1647, 1450, 1104, 1061, 863, and $617 \mathrm{~cm}^{-1}$. The peak at approximately $1400-1450 \mathrm{~cm}^{-1}$ was characteristic of the $\mathrm{C}=\mathrm{O}$ stretching bond of $\mathrm{CO}_{3}{ }^{2-}[27,43-45]$. Whereas the intensive band at $1104 \mathrm{~cm}^{-1}$ corresponded to $\mathrm{PO}_{4}{ }^{3-}[43,46]$. The peak at approximately $1061 \mathrm{~cm}^{-1}$ was attributed to the presence of $\mathrm{SiO}_{4}{ }^{2-}[27,33,36,46,47]$. However, the recorded band at approximately $863 \mathrm{~cm}^{-1}$ was distinctive to metal bonded to oxygen [42]. Mainly, the peak at approximately $617 \mathrm{~cm}^{-1}$ belonged to the bending $\mathrm{S}-\mathrm{O}$ of sulphate $\left(\mathrm{SO}_{4}{ }^{2-}\right)[43,48]$. All the indicated peaks for carbonate, phosphate, sulphate, silicate, and metal oxide were present in the form of kalicinite, langbeinite, bradleyite, nahcolite, calcite, scawtite, and spurrite of the tested ash materials as previously confirmed by XRD analysis.

Table 3. FTIR spectra assignment for raw and ash materials.

\begin{tabular}{|c|c|c|c|}
\hline \multirow{2}{*}{ Functional Groups } & \multicolumn{2}{|c|}{ Wavenumber $\mathrm{cm}^{-1}$} & \multirow{2}{*}{ Reference } \\
\hline & Raw Materials & Ash Materials & \\
\hline OH Stretching & 3401 & - & {$[32,35]$} \\
\hline $\mathrm{C}-\mathrm{H}$ bond of $\mathrm{CH}_{2}$ group & 2915 & - & {$[32,36-38]$} \\
\hline $\mathrm{O}-\mathrm{H}$ bending & 1639 & 1652 & {$[39,40,43]$} \\
\hline Carboxyl (-COOH) groups & 1749 & - & {$[32,36,37]$} \\
\hline $\mathrm{CO}$ stretching bond of $\mathrm{CO}_{3}{ }^{2-}$ & 1400 & 1450 & {$[26,38,44,45]$} \\
\hline $\begin{array}{c}\mathrm{Si}-\mathrm{O}-\mathrm{Si} \text { asymmetric } \\
\mathrm{Or} \mathrm{SiO} \\
{ }^{2-}\end{array}$ & 1064 & 1061 & {$[26,32,35,46,47]$} \\
\hline $\begin{array}{l}\mathrm{P}-\mathrm{O} \text { stretching } \\
\mathrm{PO}_{4}^{2-} \text { group }\end{array}$ & - & 1104 & {$[38,46]$} \\
\hline $\mathrm{M}-\mathrm{O}$ bond & - & 863 & {$[42,48]$} \\
\hline Bending $\mathrm{S}-\mathrm{O}$ of $\mathrm{SO}_{4}{ }^{-2}$ & - & 617 & {$[38,46]$} \\
\hline
\end{tabular}

\subsection{Assessment of the Ability of the Tested Ash Materials to Remove Ca Ions}

Based on data in Table 4, the tested ashes displayed a great affinity for diminution of $\mathrm{Ca}$ ions from the solution. The elimination efficiency was above $75 \%$ for Po-ash and Ba-ash, while Eg-ash and Min-ash were approximately $58 \%$ at extremely high initial $\mathrm{Ca}$ content (1000 ppm) as illustrated in Figure 5a. Only $10 \mathrm{~g} / \mathrm{L}$ of ash samples were sufficient to 
eliminate $58-75 \%$ of the total significantly hard water solutions. In addition, all examined ash materials increased the $\mathrm{pH}$ values for treated feed solutions without increasing the number of hydroxyl ions. Po-ash, BA-ash, and Min-ash raised the $\mathrm{pH}$ up to 9.6, while Eg-ash increased the $\mathrm{pH}$ to 8.8, which indicated that the basic nature of the ash materials was in agreement with other researchers $[25,26,49,50]$.
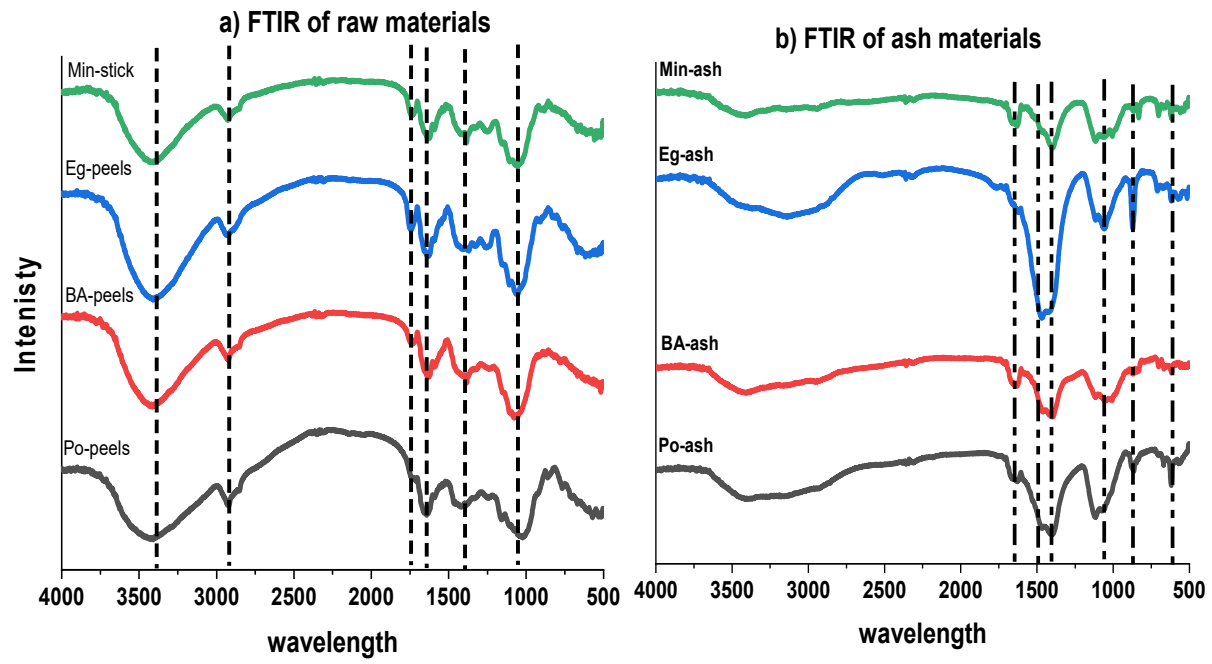

Figure 4. FTIR spectra: (a) raw materials; (b) ash materials.

Table 4. Changes in water quality after adding $10 \mathrm{~g} / \mathrm{L}$ of ash materials in $1000 \mathrm{ppm}$ Ca ions.

\begin{tabular}{ccccc}
\hline Samples & Final $\mathbf{p H}$ & $\begin{array}{c}\text { Conductivity } \\
(\mathbf{m S} / \mathbf{c m})\end{array}$ & $\begin{array}{c}\text { TDS } \\
(\mathbf{p p m})\end{array}$ & $\begin{array}{c}\text { \% } \\
\text { Removal }\end{array}$ \\
\hline Po-ash & 9.5 & 9.2 & 4729 & 75 \\
BA-ash & 9.6 & 9.2 & 4729 & 79.2 \\
Eg-ash & 8.7 & 8.8 & 4524 & 58.3 \\
Min-ash & 9.7 & 7.4 & 3806 & 58.3 \\
Blank & 7.7 & 5.19 & 2659 & - \\
$\mathrm{Ca}^{2+}: 1000$ ppm & & & & \\
\hline
\end{tabular}

Regarding conductivity and TDS measurements from Figure $5 \mathrm{~b}$ and Table 4 , the results showed a $43 \%$ increment after adding a $10 \mathrm{~g} / \mathrm{L}$ dose of ash materials for Po-ash, BA-ash, and Eg-ash, while Min-ash showed only a 30\% increment. This may be the result of existing soluble inorganic salts, e.g., $\mathrm{KCl}, \mathrm{KHCO}_{3}, \mathrm{NaCl}$, and $\mathrm{NaHCO}_{3}$, which were confirmed by XRD analysis. Other published studies displayed increments in TDS or conductivity in the same way $[26,39]$. Bearing in mind that $\mathrm{Na}^{+}$and $\mathrm{K}^{+}$ions remaining in the feed solution cannot form scale, they are also much easier to be removed with the employment of an $\mathrm{RO}$ system in order to meet the standards allowed for drinking water [51].

Changes in Water Quality by Increasing the Amount of Agro-Ash in Pure Distilled Water

First, we needed to study the nature and chemical properties of treated water after adding a definite amount of the tested ash materials, measuring the released number of cations and anions in aqueous solutions to explain the proper mechanism for removing Ca ions from solutions. The preliminary dissolution of the tested ash materials in distilled water was evaluated by mixing $1 \mathrm{~g}$ of agro-ash in $100 \mathrm{~mL}$ of distilled water with a contact time of $1 \mathrm{~h}$. The results presented in Table 5 show the water quality after treatment with agro-ash. The reported numbers show an increase in the level of $\mathrm{pH}$ values up to nine, indicating the basic character of the ash samples. All examined agro-ash reflected high conductivity (approximately $5.3-8.7 \mathrm{mS} / \mathrm{cm}$ ) and increments in TDS measurements (more than $2.6 \mathrm{~g} / \mathrm{L}$ ) for all tested samples. The large majority of cations (i.e., $\mathrm{K}^{+}, \mathrm{Na}^{+}, \mathrm{Ca}^{2+}$, and $\mathrm{Mg}^{2+}$ ) was indicated, mainly high amount of $\mathrm{K}^{+}$as well anions, particularly $\mathrm{Cl}^{-}$, 
$\mathrm{SO}_{4}{ }^{2-}, \mathrm{CO}_{3}{ }^{2-}$, and $\mathrm{HCO}_{3}{ }^{-}$. However, the amounts of sodium were small compared to the potassium content.

a) Removal of Ca ions
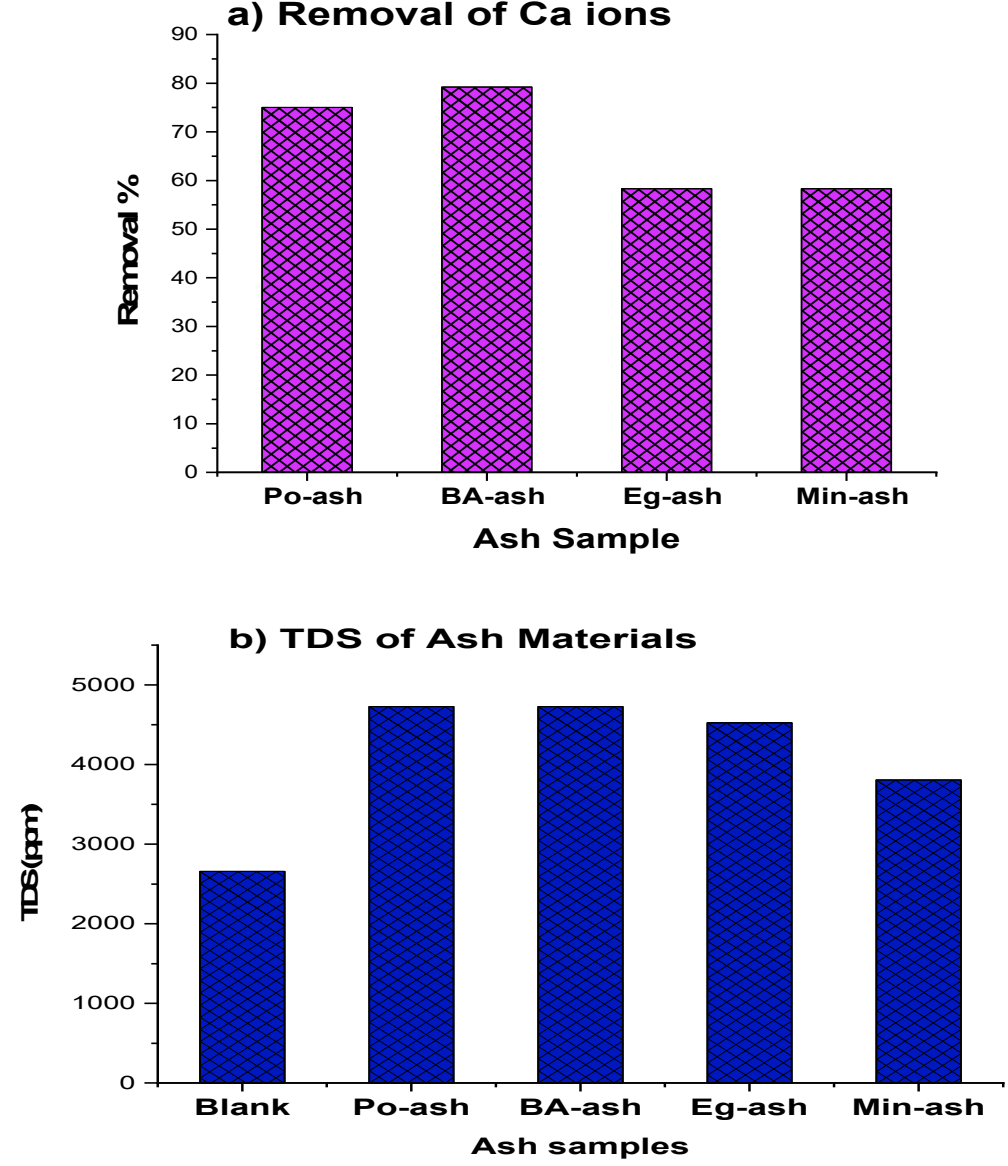

Figure 5. Comparison of the examined ash samples: (a) \%Ca removal; (b) TDS in solution.

Table 5. Quality changes in $100 \mathrm{~mL}$ of distilled water by adding $1 \mathrm{~g}$ of the tested ash.

\begin{tabular}{ccccccc}
\hline Parameters & Units & Dist. Water & Po-ash & BA-ash & Eg-ash & Min-ash \\
\hline Total hardness & $\mathrm{ppm}$ & - & 100 & 80 & 80 & 140 \\
$\mathrm{pH}$ & - & 6.9 & 9.7 & 10.3 & 10.6 & 10.7 \\
Conductivity & $\mathrm{mS} / \mathrm{cm}$ & 0.008 & 6.6 & 6.8 & 8.7 & 5.3 \\
$\mathrm{Na}^{+}$ & $\mathrm{ppm}$ & - & 54 & 6 & 99 & 196 \\
$\mathrm{~K}^{+}$ & $\mathrm{g} / \mathrm{L}$ & - & 1.64 & 1.64 & 2.34 & 1.35 \\
$\mathrm{Fe}^{2+}$ & $\mathrm{ppm}$ & - & $\mathrm{nd}$ & $\mathrm{nd}$ & $\mathrm{nd}$ & $\mathrm{nd}$ \\
$\mathrm{Mn}^{2+}$ & $\mathrm{ppm}$ & - & 0.1 & 0.1 & 0.1 & 0.1 \\
$\mathrm{Cl}^{-}$ & $\mathrm{g} / \mathrm{L}$ & - & 0.74 & 0.45 & 0.26 & 0.22 \\
$\mathrm{SO}_{4}{ }^{2-}$ & $\mathrm{g} / \mathrm{L}$ & - & 0.44 & 0.09 & 0.37 & 0.26 \\
$\mathrm{CO}_{3}{ }^{2-}$ & $\mathrm{g} / \mathrm{L}$ & - & 1.62 & 3.0 & 2.88 & 3.66 \\
$\mathrm{HCO}_{3}{ }^{-}$ & $\mathrm{g} / \mathrm{L}$ & - & 4.09 & 1.40 & 3.11 & 0.43 \\
\hline
\end{tabular}

The remarkable aspects of the tested ash materials were their significant amounts of carbonate and bicarbonate, which make them valuable resources. Po-ash and Eg-ash released the highest amounts of $\mathrm{HCO}_{3}{ }^{-}$at 410 and $310 \mathrm{ppm}$ for the presence of a mixture of $\mathrm{KHCO}_{3}$ and $\mathrm{NaHCO}_{3}$. While Min-ash, BA-ash, and Eg-ash released a high quantity of $\mathrm{CO}_{3}{ }^{2-}$ in agreement with the previous mineralogical analyses of the XRD patterns (see Section 3.1.): $\mathrm{Na}_{3} \mathrm{Mg}\left(\mathrm{PO}_{4}\right) \mathrm{CO}_{3}, \mathrm{Ca}_{7}\left(\mathrm{Si}_{6} \mathrm{O}_{18}\right)\left(\mathrm{CO}_{3}\right)\left(\mathrm{H}_{2} \mathrm{O}\right)_{2}, \mathrm{Ca}_{5}\left(\mathrm{SiO}_{4}\right)_{2} \mathrm{CO}_{3}$, and $\mathrm{CaCO}_{3}$. 


\subsection{The Proper Mechanism for the Removal of Ca Ions from an Aqueous System}

Details derived from all analysis techniques of the burned ashes about their definite compositions helped in the prediction of the appropriate mechanism for removal of $\mathrm{Ca}$ ions from the aquatic system. Data derived from the XRD patterns indicated various soluble and non-soluble minerals such as carbonate and bicarbonate structures: nahcolite, kalicinite, bradleyite, calcite, scawtite, and spurrite. All alkali metals' carbonates or bicarbonates are highly soluble in water at a lower $\mathrm{pH}$ values, while other types of carbonates, such as $\mathrm{CaCO}_{3}(\mathrm{~s})$, are hardly soluble at higher $\mathrm{pH}$ levels [50]. Therefore, the existence of enormously soluble alkali bicarbonates $\left(\mathrm{NaHCO}_{3}\right.$ and $\left.\mathrm{KHCO}_{3}\right)$ was responsible for the rapid augment in $\mathrm{pH}$ values and the formation of metal hydroxide at high rates according to the reactions described below $[8,17,52]$. The successive Equations (2)-(4) are:

$$
\mathrm{MHCO}_{3}(\mathrm{~s})+2 \mathrm{H}_{2} \mathrm{O}(\mathrm{l}) \rightarrow 2 \mathrm{MOH}(\mathrm{aq})+\mathrm{H}_{2} \mathrm{CO}_{3}(\mathrm{aq})
$$

where $\mathrm{M}=\mathrm{Na}^{+}$or $\mathrm{K}^{+}$.

$$
\begin{gathered}
\mathrm{HCO}_{3}{ }^{-}+\mathrm{OH}^{-} \rightarrow \mathrm{CO}_{3}{ }^{2-}+\mathrm{H}_{2} \mathrm{O} \\
\mathrm{Ca}^{2+} \text { (aq.) }+\mathrm{CO}_{3}{ }^{2-} \text { (aq.) } \rightarrow \mathrm{CaCO}_{3} \text { (s) } \downarrow
\end{gathered}
$$

The predicted mechanism for the removal of calcium ions can be explained by two factors. The first dominant one came from hydrolysis of various soluble carbonates and bicarbonates present in the ash materials which can (i) enhance hydroxyl ion formation leading to dramatic increases in the $\mathrm{pH}$ of the solution, as demonstrated in Tables 4 and 5, which can form sodium and potassium hydroxides that play the same role as lime in water softening as a source of alkali. (ii) The existence of carbonates and bicarbonates in the solution were easily converted to noncarbonated $\mathrm{Ca}$ ions in the solution to an insoluble form of $\mathrm{CaCO}_{3}$ [52]. (iii) After increasing the $\mathrm{pH}$ of the solution, the bicarbonate radicals easily react with hydroxyl ions to form a carbonate radical that can react with $\mathrm{Ca}^{2+}$ [17]. The second mechanism may enhance the reduction in $\mathrm{Ca}^{2+}$ ions due to the adsorption role of insoluble inorganic minerals existing in the composition of agro-ash such as charcoal, silicates, and $\mathrm{CaCO}_{3}$ [50]. Precipitation by alkali/carbonate sources is a familiar method used for reducing the hardness of water [11,14,52-54]. $\mathrm{Mg}(\mathrm{OH})_{2}$ was used as an alkali source derived from the brine pre-treated waste of soda ash plant mixed with the flux of $\mathrm{CO}_{2}$ for water decalcification by precipitation of $\mathrm{CaCO}_{3}$ [17]. In addition, ash derived from coal plants is used as strong alkali material, showing a high $\mathrm{pH}$ value in the range 10-13, and it was utilized as a chemical precipitant in an aqueous solution [55]. Moreover, ashes derived from bamboo, rice husk, banana rind, and banana pseudostems were used as a precipitant for iron removal from groundwater [25]. Furthermore, $\mathrm{NaHCO}_{3}$ and limestone were studied in a previous work to increase the alkalinity in aqueous solutions and facilitate precipitation of $\mathrm{Cd}, \mathrm{Pb}, \mathrm{Zn}, \mathrm{Ni}, \mathrm{Cu}$, and $\mathrm{Cr}$ ions from solutions [56]. The precipitation process is easily available in high basic solutions for the removal of $\mathrm{Ca}$ and $\mathrm{Sr}$ ions by lime and bicarbonate [57] and for $\mathrm{Cu}$ ions by using ash from coal-fired power plants [56].

\section{Analysis of the Residue Agro-Ash during the Precipitation Process}

The above mechanism (Section 3.5.) was confirmed by analysis of the residual ash materials after mixing the agro-ash with a feed solution containing $\mathrm{Ca}^{2+}$. The formation of $\mathrm{CaCO}_{3}$ was indicated by XRD analysis that pointed to the presence of synthetic $\mathrm{CaCO}_{3}$ in the form of a calcite structure as illustrated in Figure 6. The XRD spectrographs of synthetic calcite $\left(\mathrm{CaCO}_{3}\right)$ demonstrated eight distinctive peaks according to JCPDS card no. 05-0586. The illustrating crystal planes were (012), (104), (110), (113), (202), (018), (116), and (122), and they appeared at $2 \theta=22.99,29.36,35.94,39.52,43.32,47.55,48.60$, and $57.54^{\circ}$, while their diffraction lines were observed at $\mathrm{d}=3.84,3.02,2.48,2.27,2.08,1.91,1.87$, and 1.60 [58]. According to the results obtained from the XRD peaks, only one phase structure of $\mathrm{CaCO}_{3}$ was formed as calcite, but the other phases, such as vaterite or aragonite, cannot form under these conditions $[14,58]$. 


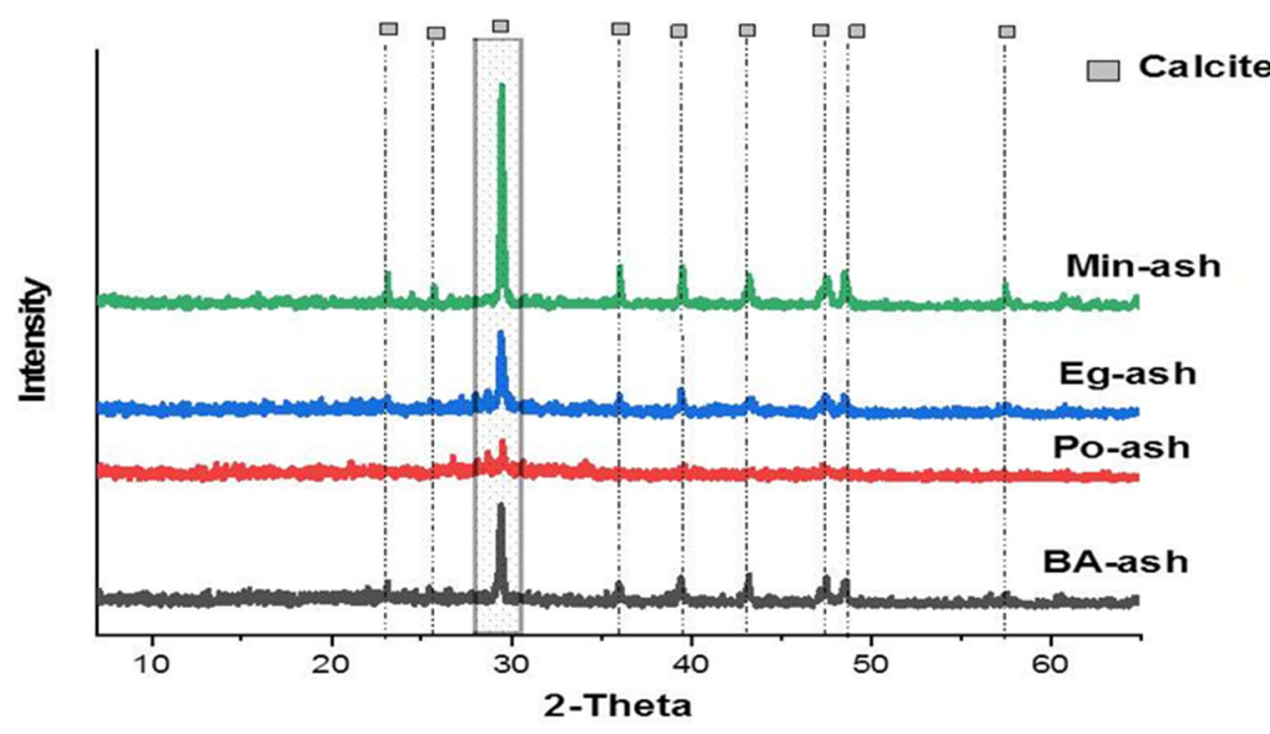

Figure 6. $\mathrm{XRD}$ of $\mathrm{CaCO}_{3}$ precipitating in the residue of agro-ash material presenting in the calcite phase.

\subsection{Influence of the Initial Calcium Concentrations on the Removal Process}

Reduction of Ca (II) as a hardness ion is significantly controlled by the initial concentrations of aqueous resources. The influence of initial calcium ion concentration on the removal process was examined at a fixed ash mass $(10 \mathrm{~g} / \mathrm{L})$ and is revealed in Figure $7 \mathrm{a}$. The increasing concentration of Ca ions from 500 to $4000 \mathrm{mg} / \mathrm{L}$ showed a noticeable decrease in the elimination affinity. The removal of Ca ions reached nearly $80 \%$ (at an initial concentration of $500 \mathrm{ppm}$ ) for all the tested ash materials. However, increasing the initial concentration above $3000 \mathrm{ppm}$ showed a dramatic decrease in removal efficiency to $20 \%$. The reason for such behavior may be explained by the limited activity of ash materials at a fixed dose $(10 \mathrm{~g} / \mathrm{L})$, and the used dosage was not adequate for the reduction of high-level contents of $\mathrm{Ca}$ ions $[18,44]$. Hence, with an increase in the initial $\mathrm{Ca}^{2+}$ ions, more ash must be added to release more hydroxide and carbonate ions to enhance the precipitation of $\mathrm{Ca}^{2+}$ ions from the solution [25]. A noteworthy, good relationship between the initial concentration of $\mathrm{Ca}$ ions and $\mathrm{pH}$ of the feed solution was observed. For a fixed dose of $10 \mathrm{~g} / \mathrm{L}$ of tested ash samples, increasing the initial Ca ion content (from 500 to $4000 \mathrm{ppm}$ ) resulted in a decline in the $\mathrm{pH}$ of the solution from 10 to 8.0 as demonstrated in Figure $7 \mathrm{~b}$. This decrease in the final $\mathrm{pH}$ value can be explained by the dissolution of the high level of $\mathrm{CaCl}_{2} \cdot 6 \mathrm{H}_{2} \mathrm{O}$ in a solution that lowered the $\mathrm{pH}$ of the aqueous solutions and became more acidic, less than seven [59]. Therefore, the added amount of agro-ash consumed part of them to neutralize these acidic solutions.

\subsection{Influence of the $\mathrm{pH}$ of the Solution}

Removal of metal ions are strongly governed by $\mathrm{pH}$ values in water and wastewater engineering. The influence of changing $\mathrm{pH}$ values on the removal of $\mathrm{Ca}$ ions with the tested ash materials was investigated and is illustrated in Figure 8. All examined ashes showed augments in final $\mathrm{pH}$ values of the feed solution from faintly alkaline ( $\mathrm{pH}$ 8.2) to an extremely high basic medium ( $\mathrm{pH}$ 9.8). The tested ash substance increased the $\mathrm{pH}$ values of treated water in the following order: Min-ash $>$ BA-ash $\approx$ Po-ash $>$ Eg-ash. Similar observations were reported for various fly ash and biochar materials exhibiting a basic nature and an increase in the alkalinity of the aqueous solution $[16,25,26,44,50]$. With the increasing $\mathrm{pH}$ of the feed solution, the reduction rate for $\mathrm{Ca}$ ions was enhanced. In $\mathrm{pH}$ values lower than three, the reduction did not exceed $25 \%$ of the total Ca content. Decreasing the $\mathrm{pH}$ values of the aqueous solution to less than 4.3 converted bicarbonate into carbonic acid, while the increasing the alkalinity of the solutions helped in the conversion of bicarbonates into carbonates and, consequently, the easy removal of calcium as $\mathrm{CaCO}_{3}$ [54]. 
Moreover, the precipitate of calcium carbonate began to dissolve in acidic conditions [17]. Thus, a fast removal of $\mathrm{Ca}$ ions was obtained beyond $\mathrm{pH} 5$ and the increasing onset of the precipitation process [50]. The appropriate $\mathrm{pH}$ for the precipitation of calcium carbonate was 9.5 [14], and the carbonation process for the precipitation of $\mathrm{CaCO}_{3}$ was not stopped as soon as the $\mathrm{pH}$ values did not drop to a $\mathrm{pH}$ lower than seven. Hence, a large amount of ash material is recommended to neutralize the acidic nature of feed solutions. The increasing $\mathrm{pH}$ value from 9.5 to 10.5 may also help in removing other heavy metals, such as iron, manganese, lead, copper, zinc, and arsenic, by precipitation [60].
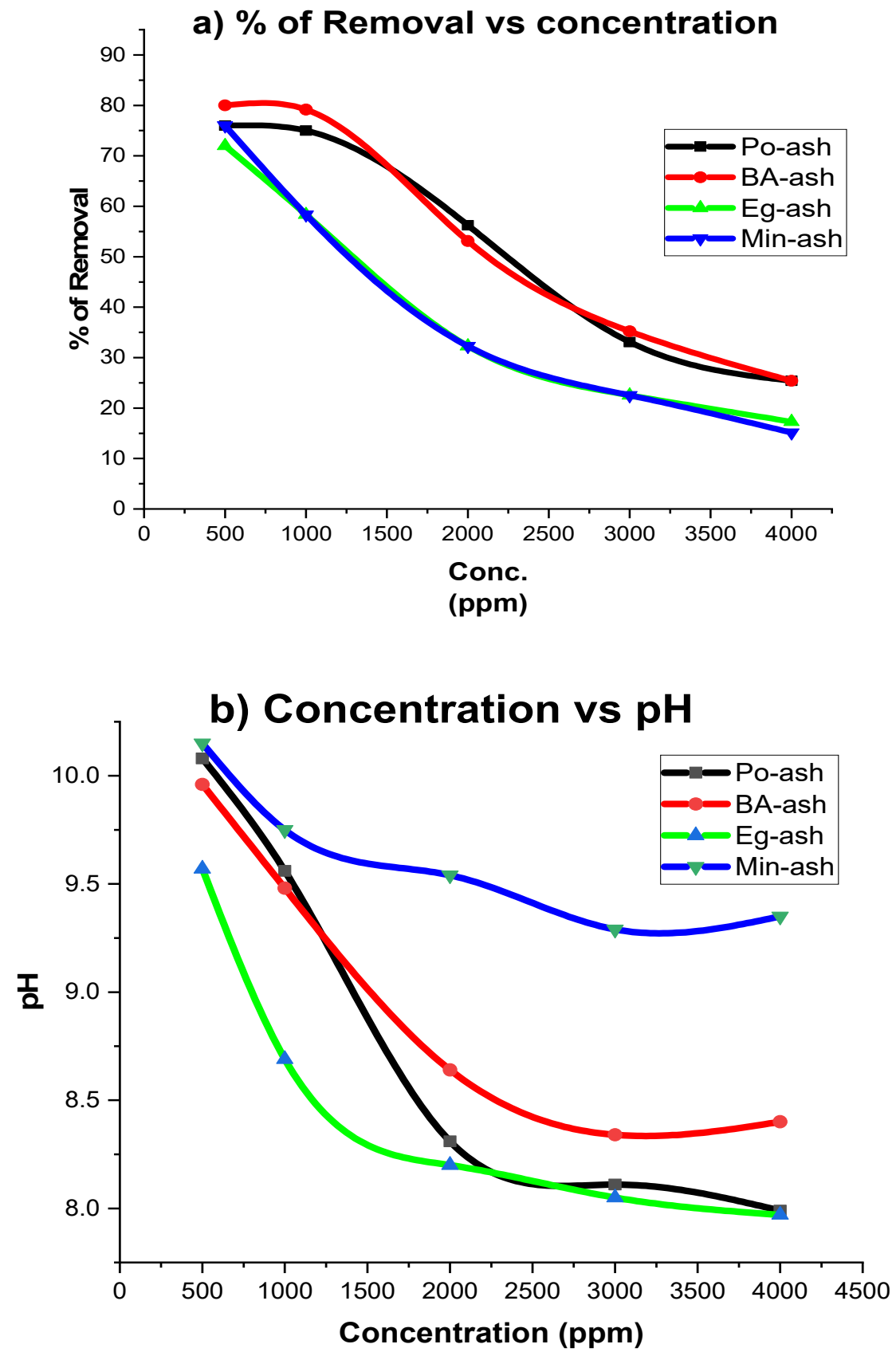

Figure 7. Influence of the initial concentrations against the removal of $\mathrm{Ca}$ ions in (a) versus the $\mathrm{pH}$ in (b) of the solution.

\subsection{Studying the Mass of Ash Materials}

Adsorbent dosage is an important parameter for determining the capacity of the materials; therefore, we can ascertain the optimum dose for the maximum extent of removal. Figure 9a illustrates the ability of examined agro-ash dosages on the removal ability of 
calcium ions. It can easily be pointed out from the obtained results that the percentage of $\mathrm{Ca}$ ion removal increased with an increase in the used amount of ash materials. The increased dose, from 2 to $14 \mathrm{~g} / \mathrm{L}$, increased the efficiency of Ca removal from $8 \%$ to approximately $82 \%$ in for Po-ash and BA-ash and $66 \%$ for Min-ash and Eg-ash. A sharp increase in the removal efficiency after a dose of $6 \mathrm{~g} / \mathrm{L}$ was observed. Therefore, the employed dosage of ash at $10 \mathrm{~g} / \mathrm{L}$ was quiet enough to achieve $80 \%$ removal efficiency for Po-ash and BA-ash, while Min-ash and Eg-ash provided only 58\% Ca removal. Higher amounts of ash provide more soluble carbonate and bicarbonate that raises the $\mathrm{pH}$ of the solution and enhances the precipitation conditions of $\mathrm{Ca}$ ions [25,54]. Moreover, a remarkable enhancement in the $\mathrm{pH}$ of the aqueous solution was accompanied by an increasing amount of added ash mass as presented in Figure $9 \mathrm{~b}$. This large increase in $\mathrm{pH}$ values of the solution was due to the rapid dissolution of all soluble alkali bicarbonate and carbonate presented in the tested ash compositions [25,50]. This increase in $\mathrm{pH}$ during the softening experiment was similar to the increase in the action of lime [14], even though by adding a small quantity of ash, the $\mathrm{pH}$ values increased to 8.5. Furthermore, an assessment of the increase in the total TDS and conductivity measurements was indicated (as presented in Table 3) due to the basic character of the tested ash materials. Utilization of the (RO) system was needed for further purification of the water from soluble $\mathrm{Na}^{+}$and $\mathrm{K}^{+}$cations to meet the quality standards of drinking water [32].

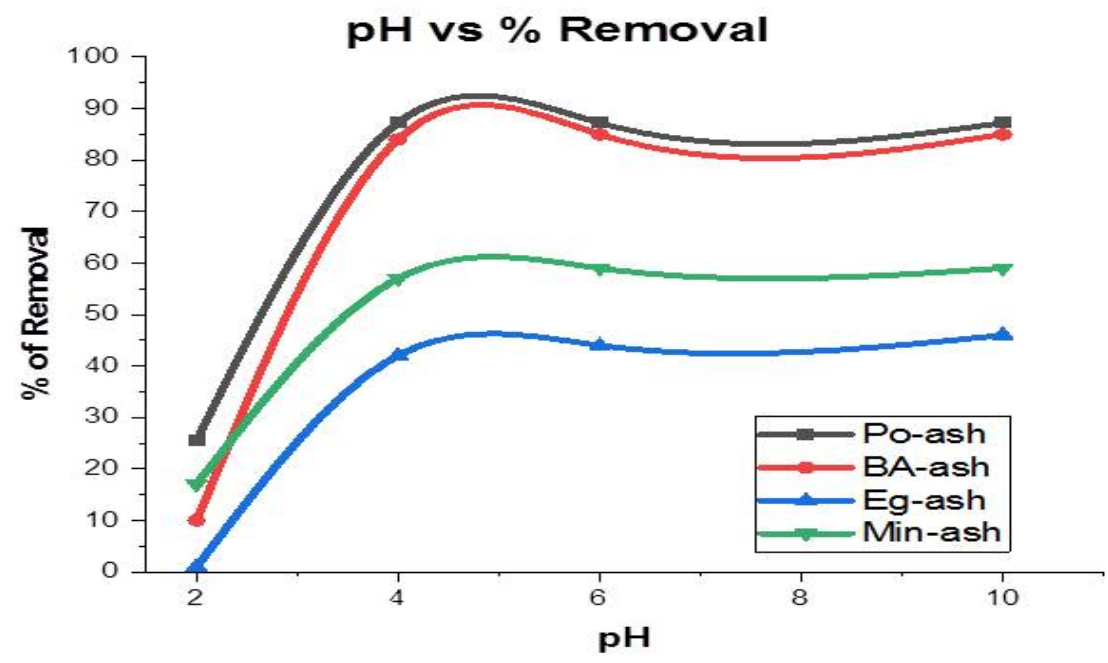

Figure 8. The influence of $\mathrm{pH}$ on the Removal of $\mathrm{Ca}$ ions.

\subsection{Contact Time}

The elimination rate of $\mathrm{Ca}$ ions from solutions is considered an essential factor for designing reactors for effective practical purposes [61]. The results of studying the effect of contact time between the ago-ash and feed solution are shown in Figure 10a. Another extra feature of using agro-ash materials (besides their application as an alternative method to the lime/soda ash method) is their rapid elimination of major hardness ions $\left(\mathrm{Ca}^{2+}\right)$ within $5 \mathrm{~min}$, especially when compared to other methods. No more than ten minutes were needed to complete the removal of Ca ions as shown in Figure 10a, even though other published studies have demonstrated that more time was required for attending to the equilibrium of Ca ion removal. The equilibrium times were $240 \mathrm{~min}$ by modified pumice [39], $180 \mathrm{~min}$ by white clay [17], $24 \mathrm{~h}$ by ureolytic microbiological carbonate precipitation [6], $10 \mathrm{~min}$ by [4,4'-isopropylidenebis (phenoxyacetate)] [11], 3 days by utilization of the microbial carbonate precipitation process [9], $10 \mathrm{~min}$ by using wheat straw and rice husk ashes [16], and $90 \mathrm{~min}$ by modified bentonite [33]. The fact that there was no need to increase the contact time of the examined agro-ash with solutions by more than $30 \mathrm{~min}$ in most cases of Po-ash, BA-ash, Eg-ash, and Min-ash was considered. In addition, no significant increment in the $\mathrm{pH}$ of solutions with an increase in the contact time was observed as illustrated in Figure 10b. The feed solutions entered a steady state in approximately $60 \mathrm{~min}$. 

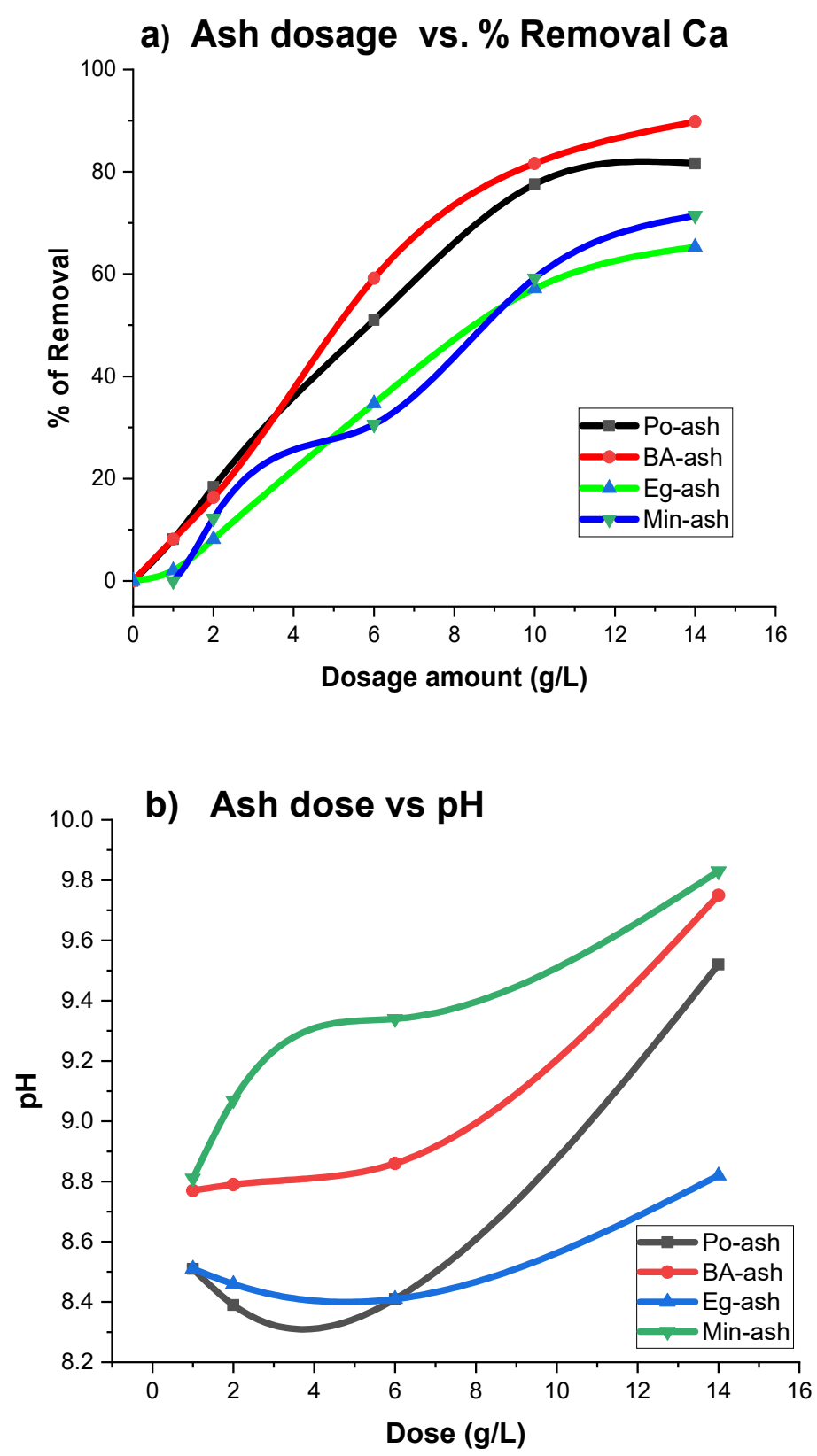

Figure 9. (a) Influence of ash dose versus Ca removal; (b) influence of ash dose versus $\mathrm{pH}$.

\subsection{Comparison between Common Precipitation Methods and Tested Agro-Ash}

Several laboratory examinations were carried out to compare various conventional methods with the examined agro-ash for removal of $\mathrm{Ca}$ ions, bearing in mind that Ca ions are the primary cation that creates scales when presented in water samples. Hydrated lime, soda ash, and caustic soda are considered the most cost-effective substances frequently used in water plants, and the required lime dosages for water softening are approximately 100-200 mg/1 [60]. In this study, five commonly substances were utilized: $\mathrm{NaOH}, \mathrm{Ca}(\mathrm{OH})_{2}$, $\mathrm{NaHCO}_{3}, \mathrm{Na}_{2} \mathrm{CO}_{3}$, and $\mathrm{CaO}$ and the two mixtures of $\mathrm{CaO}$ and $\mathrm{Na}_{2} \mathrm{CO}_{3}$ and $\mathrm{Ca}(\mathrm{OH})_{2}$ and $\mathrm{Na}_{2} \mathrm{CO}_{3}$ compared with the tested ago-ashes. The results are demonstrated in Table 6, and the efficiency of Po-ash and BA-ash showed higher calcium removal by approximately $75 \%$ more than $\mathrm{NaHCO}_{3}$ or $\mathrm{Na}_{2} \mathrm{CO}_{3}(60 \%)$ in high initial concentration of Ca ions of $1000 \mathrm{ppm}$. Moreover, the Eg-ash and Min-ash also showed good removal of $\mathrm{Ca}$ at approximately $58 \%$, which was very close to the results of the treatment with $\mathrm{NaHCO}_{3}$ or $\mathrm{Na}_{2} \mathrm{CO}_{3}$. The tested agro-ash materials used in the water treatment were accessible and free of charge, and they were cost-effective and environmentally benign materials unlike other 
chemical precipitants, such as $\mathrm{NaOH}, \mathrm{Ca}(\mathrm{OH})_{2}, \mathrm{NaHCO}_{3}, \mathrm{Na}_{2} \mathrm{CO}_{3}$, and $\mathrm{CaO}$, which must be purchased. There was also no necessity to further use chemicals in the treatment process or make any modifications to the agro-ash materials. This made the demand for agro-ash more significant than conventionally used lime, limestone, soda ash, or any other industrial chemicals which are expensive [50]. Other researchers studied the reuse of different alkali sources, such as $\mathrm{Mg}(\mathrm{OH})_{2}$ and $\mathrm{CaCO}_{3}$, for the pre-treatment of seawater [17] using basic oxygen furnace slag (BOF) and the soda ash-lime method to treat acid mine drainage [51]. In addition, Namibian charcoal ash from acid mine drainage was used in the elimination of metals and sulphate ions [50], while boiler fly ash (RBFA) was used to remove $\mathrm{Pb}, \mathrm{Cd}$, and $\mathrm{Zn}$ ions from the cycle of kraft pulp mills [62]. Other agricultural ash materials, such as wheat straw and rice husk ash, were used to eliminate hardness ions from the solution [16].
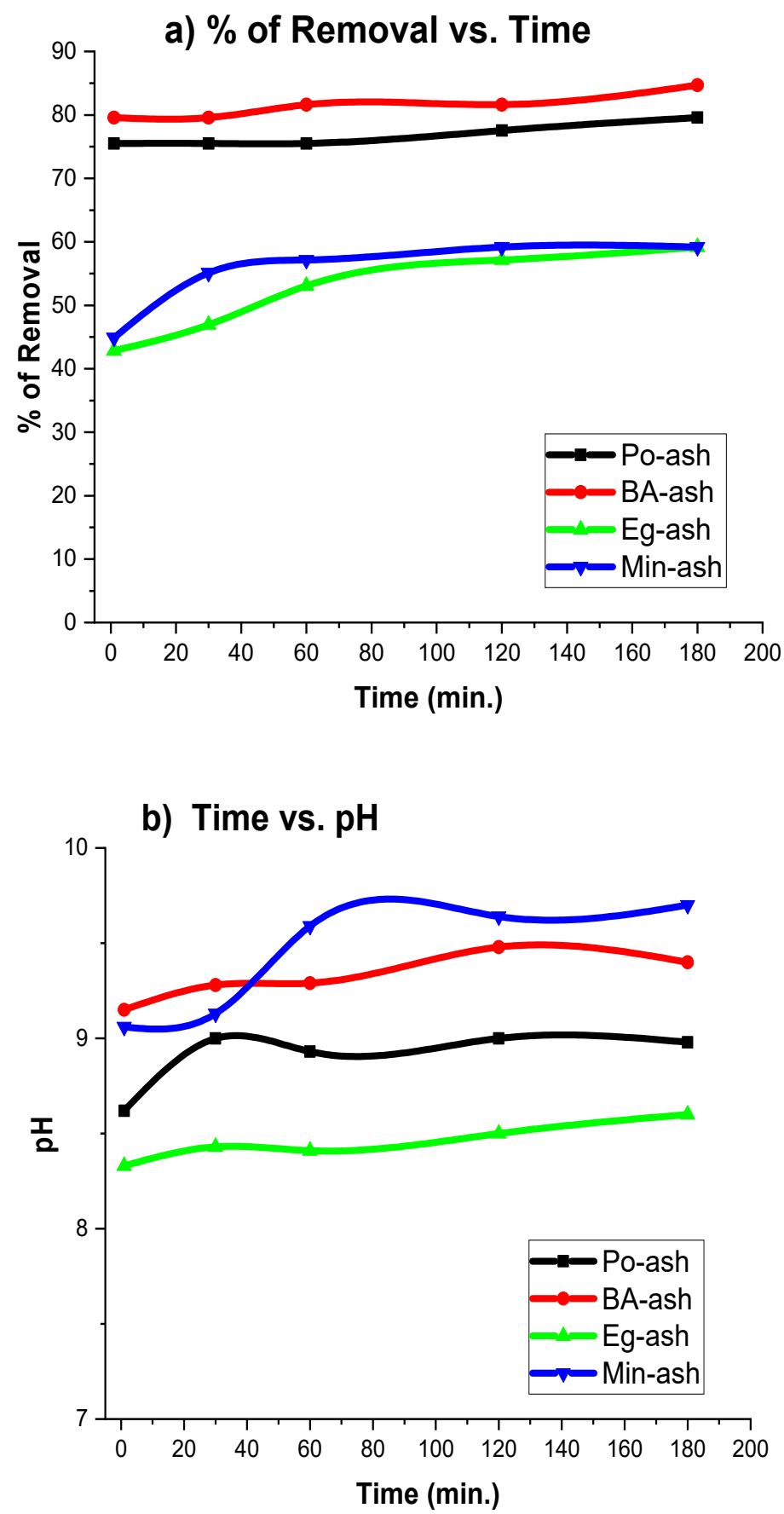

Figure 10. (a) Contact time versus removal of Ca ions; (b) contact time versus $\mathrm{pH}$ of the solution. 
Table 6. Comparison of common chemical precipitation methods with agro-ash.

\begin{tabular}{ccccc}
\hline Reagents & $\mathbf{p H}$ & $\begin{array}{c}\text { Cond. } \\
(\mathbf{m S} / \mathbf{c m})\end{array}$ & $\begin{array}{c}\text { TDS } \\
(\mathbf{g} / \mathrm{L})\end{array}$ & $\begin{array}{c}\text { \% } \\
\text { Removal }\end{array}$ \\
\hline $0.2 \% \mathrm{NaOH}$ & 12.3 & 13.4 & 6.73 & $10 \%$ \\
$0.2 \% \mathrm{NaHCO}_{3}$ & 7.87 & 5.99 & 2.99 & $60 \%$ \\
$0.2 \% \mathrm{Na}_{2} \mathrm{CO}_{3}$ & 8.22 & 5.51 & 2.75 & $72 \%$ \\
$0.2 \% \mathrm{Ca}(\mathrm{OH})_{2}$ & 12.2 & 12.7 & 6.18 & Increment \\
$0.2 \% \mathrm{Ca}(\mathrm{OH})_{2}+0.2 \% \mathrm{Na}_{2} \mathrm{CO}_{3}$ & 11.6 & 7.04 & 3.52 & $60 \%$ \\
$0.2 \% \mathrm{CaO}+0.2 \% \mathrm{Na}_{2} \mathrm{CO}_{3}$ & 12.3 & 11.2 & 5.62 & $10 \%$ \\
$\mathrm{PO}-\mathrm{ash}(0.5 \mathrm{~g} / \mathrm{L})$ & 9.5 & 9.2 & 4.72 & 75 \\
$\mathrm{BA}-\mathrm{ash}(0.5 \mathrm{~g} / \mathrm{L})$ & 9.6 & 9.2 & 4.72 & $79 \%$ \\
Eg-ash $(0.5 \mathrm{~g} / \mathrm{L})$ & 8.7 & 8.8 & 4.52 & $58 \%$ \\
$\mathrm{Min}-\mathrm{ash}(0.5 \mathrm{~g} / \mathrm{L})$ & 9.7 & 7.4 & 3.80 & $58 \%$ \\
Blank $\left(1000 \mathrm{ppm} \mathrm{CaCl}{ }_{2}\right)$ & 7.7 & 5.19 & 2.65 & - \\
\hline
\end{tabular}

\subsection{SWOT Analysis for Using the Tested Agro-Ash as an Alternative Method}

The SWOT analysis was created by Albert S. Humphrey as a simplistic tool for evaluating various technical choices and assessment methods. This approach examines both a future technology's internal strengths and weaknesses and external environmental opportunities and threats in order to determine its flaws [63]. SWOT analysis assesses the positive and negative perspectives of different variables on the system's long-term sustainability. The SWOT analysis (Table 7) was used in this study to pay attention to the worth of producing ash material from agro-waste using combustion and gasification processes. It was revealed that the tested biomass had the least expensive impact on water decalcification among the other biomasses.

Table 7. SWOT analysis for using green agro-ashes.

\begin{tabular}{|c|c|c|}
\hline \multicolumn{3}{|c|}{ SWOT Analysis } \\
\hline & Strength & Weakness \\
\hline 1. & $\begin{array}{l}\text { Tested agro-ash materials have significant levels of carbonates and } \\
\text { bicarbonates, which make them alternative resources. }\end{array}$ & \\
\hline 2. & $\begin{array}{l}\text { In the elimination of hardness in water purification, agro-ashes are } \\
\text { an effective substitute for soda ash and } \mathrm{CaO} \text { materials. }\end{array}$ & \\
\hline 3. & $\begin{array}{l}\text { The use of agro ashes is a simple way to eliminate scale formation } \\
\text { in the industrial sector. }\end{array}$ & $\begin{array}{l}\text { 1. TDS levels were } 30 \text { percent higher in treated } \\
\text { water than in untreated water. }\end{array}$ \\
\hline 4. & $\begin{array}{l}\text { The ability of ash compounds was successful even when the initial } \\
\text { Ca level was extremely high (1000 ppm). }\end{array}$ & $\begin{array}{l}\text { 2. Scales will not form in the presence of leftover } \\
\mathrm{Na} \text { and } \mathrm{K} \text { ions in the solution. }\end{array}$ \\
\hline 5. & The ash products include no hazardous chemicals. & An $\mathrm{RO}$ unit is needed to remove $\mathrm{Na}$ and $\mathrm{K}$ ions. \\
\hline 6. & $\begin{array}{l}\text { Collecting and reusing agro-ash will provide a safe method for } \\
\text { achieving a pollution-free environment. }\end{array}$ & \\
\hline 7. & Low operating and maintenance costs. & \\
\hline 8. & Agro-ash eliminated calcium ions from water in a very short time. & \\
\hline \multicolumn{2}{|r|}{ Opportunities } & Threats \\
\hline 1. & $\begin{array}{l}\text { Promotion of ash derived from agro-wastes as alternative } \\
\text { substances to precipitate heavy metals from water resources. }\end{array}$ & \multirow{6}{*}{$\begin{array}{l}\text { Concerns about air pollution produced by the } \\
\text { combustion of agricultural waste. }\end{array}$} \\
\hline 2. & Substitution of $\mathrm{Ca}(\mathrm{OH})_{2}$ by natural material. & \\
\hline 3. & $\begin{array}{l}\text { Amendments prevent rubbish from accumulating and landfills } \\
\text { from expanding. }\end{array}$ & \\
\hline 4. & Developing in-depth studies in the field of waste management. & \\
\hline 5. & Applying the 3R strategy (reduce, reuse, and recycle). & \\
\hline 6. & $\begin{array}{l}\text { Any other green biomass appears to be acceptable for } \\
\text { agro-ash production. }\end{array}$ & \\
\hline
\end{tabular}




\section{Conclusions}

Scale formation is one of the challenges that face the industrial sector, and it is strongly related to economic activities and water services. Examined agro-ash in this work showed a great ability to reduce $\mathrm{Ca}$ ions from aquatic resources. The elimination efficiency was above $75 \%$ for Po-ash and Ba-ash, while Eg-ash and Min-ash showed approximately $58 \%$ at extremely high initial Ca contents (1000 ppm). The extraordinary features of the tested agro-ash materials were significant levels of carbonates and bicarbonates, which make them valuable resources. Thus, agro-ash may be a green alternative method to employing lime/soda ash or caustic soda. The ash materials are not toxic substances; they are by-products of natural plants. Only $10 \mathrm{~g} / \mathrm{L}$ of ash samples was sufficient to remove $58-75 \%$ of the total very hard water solutions. The efficiency of Po-ash and BA-ash for the decalcification process exhibited higher removal ability $(75 \%)$ compared to consumption of $\mathrm{NaHCO}_{3}$ or $\mathrm{Na}_{2} \mathrm{CO}_{3}(60 \%)$. Moreover, there was no necessity for modifications to the agro-ash materials or the utilization of additional chemicals. Collecting and reusing agro-ash is a good method for obtaining a clean environment free of pollution. Overall, elimination of fouling and scaling is a vital issue in remediation of industrial wastewater before using an RO system to prolong the membrane's lifespan. Sustainable use of waste and expansion in green eco-friendly substances may help to save our resources and deflate treatment costs.

Author Contributions: Conceptualization, S.E.-N.; methodology, A.S.A.; software, H.M.A.; validation, S.E.-N., A.S.A. and H.M.A.; formal analysis, H.M.A.; investigation, H.S.E.D.; resources, M.M.A.-K., A.G.A.; data curation, S.E.-N.; writing—original draft preparation, S.E.-N.; writingreview and editing, S.E.-N.; supervision, S.E.-N.; project administration, M.M.A.-K.; funding acquisition, A.G.A. All authors have read and agreed to the published version of the manuscript.

Funding: This research was funded by Imam Mohammad Ibn Saud Islamic University, grant number RG-21-09-79.

Institutional Review Board Statement: Not applicable.

Informed Consent Statement: Not applicable.

Data Availability Statement: Did not report any data.

Acknowledgments: The authors extend their appreciation to the Deanship of Scientific Research at Imam Mohammad Ibn Saud Islamic University for funding this work through Research Group no. RG-21-09-79.

Conflicts of Interest: The authors declare no conflict of interest and that they have no known competing financial interests or personal relationships that could have appeared to influence the work reported in this paper.

\section{References}

1. Naushad, M.; Lichtfouse, E. Green Materials for Wastewater Treatment; Springer Nature: Cham, Switzerland, 2020.

2. Foo, K.Y.; Hameed, B.H. Utilization of rice husk ash as novel adsorbent: A judicious recycling of the colloidal agricultural waste. Adv. Colloid Interface Sci. 2009, 152, 39-47. [CrossRef]

3. Norling, P.; Wood-Black, F.; Masciangioli, T.M. (Eds.) Water and Sustainable Development: Opportunities for the Chemical Sciences-A Workshop Report to the Chemical Sciences Roundtable; National Academies Press: Washington, DC, USA, 2004.

4. Water and Jobs: Facts and Figures, Report; The United Nations World Water Development, UNESCO: Perugia, Italy, 2016; Available online: http:/ / www.unesco.org/water/wwap (accessed on 10 August 2021).

5. Nam, J.-S.; Baek, I.-H.; Kim, C.Y. Removal of Calcium Ions from Aqueous Solution by Phosphosilicate Glass. J. Am. Ceram. Soc. 2011, 94, 124-129. [CrossRef]

6. Hammes, F.; Seka, A.; de Knijf, S.; Verstraete, W. A novel approach to calcium removal from calcium-rich industrial wastewater. Water Res. 2003, 37, 699-704. [CrossRef]

7. Shakkthivel, P.; Sathiyamoorthi, R.; Vasudevan, T. Development of acrylonitrile copolymers for scale control in cooling water systems. Desalination 2004, 164, 111-123. [CrossRef]

8. Ketrane, R.; Saidani, B.; Gil, O.; Leleyter, L.; Baraud, F. Efficiency of five scale inhibitors on calcium carbonate precipitation from hard water: Effect of temperature and concentration. Desalination 2009, 249, 1397-1404. [CrossRef] 
9. Hammes, F.; Seka, A.N.; van Hege, K.; van de Wiele, T.; Vanderdeelen, J.; Siciliano, S.D.; Verstraete, W. Calcium removal from industrial wastewater by bio-catalytic CaCO3 precipitation. J. Chem. Technol. Biotechnol. 2003, 78, 670-677. [CrossRef]

10. Ye, Z.-L.; Hong, Y.; Pan, S.; Huang, Z.; Chen, S.; Wang, W. Full-scale treatment of landfill leachate by using the mechanical vapor recompression combined with coagulation pretreatment. Waste Manag. 2017, 66, 88-96. [CrossRef]

11. Ni, S.; Wu, C.; Wang, Y.; Guo, X.; Zhao, Z.; Sun, X. An extraction and precipitation process for the removal of Ca and Mg from ammonium sulfate rare earth wastewaters. Hydrometallurgy 2019, 187, 63-70. [CrossRef]

12. Xia, M.; Ye, C.; Pi, K.; Liu, D.; Gerson, A.R. Ca removal and Mg recovery from flue gas desulfurization (FGD) wastewater by selective precipitation. Water Sci. Technol. 2017, 76, 2842-2850. [CrossRef] [PubMed]

13. Kim, J.; Jain, A.; Zuo, K.; Verduzco, R.; Walker, S.; Elimelech, M.; Zhang, Z.; Zhang, X.; Li, Q. Removal of calcium ions from water by selective electrosorption using target-ion specific nanocomposite electrode. Water Res. 2019, 160, 445-453. [CrossRef]

14. Farmanbordar, S.; Kahforoushan, D.; Fatehifar, E. A new method in the removal of Ca and Mg ions from industrial wastewater. Desalination Water Treat. 2015, 57, 8904-8910. [CrossRef]

15. Erkan, H.S.; Engin, G.Ö. Calcium removal from calcium rich paper mill wastewater by microbial CaCO3 precipitation. Balıkesir Üniversitesi Fen Bilimleri Enstitüsü Dergisi 2019, 352-363. [CrossRef]

16. Kharel, H.L.; Sharma, R.K.; Kandel, T.P. Water Hardness Removal Using Wheat Straw and Rice Husk Ash Properties. Nepal J. Sci. Technol. 2016, 17, 11-16. [CrossRef]

17. Zhao, Y.; Zhang, Y.; Liu, J.; Gao, J.; Ji, Z.; Guo, X.; Liu, J.; Yuan, J. Trash to treasure: Seawater pretreatment by CO2 mineral carbonation using brine pretreatment waste of soda ash plant as alkali source. Desalination 2017, 407, 85-92. [CrossRef]

18. El-Nahas, S.; Osman, A.I.; Arafat, A.S.; Al-Muhtaseb, A.H.; Salman, H.M. Facile and affordable synthetic route of nano powder zeolite and its application in fast softening of water hardness. J. Water Process. Eng. 2020, 33, 101104. [CrossRef]

19. United Nations Environment Programme (UNEP). The Sound Management of Chemicals and Wastes in the Context of the Sustainable Development Goals: Links between the Basel, Rotterdam and Stockholm Conventions and the 2030 Agenda for Sustainable Development; UNEP Division for Environmental Law and Conventions: Nairobi, Kenya, 2016.

20. Voshell, S.; Mäkelä, M.; Dahl, O. A review of biomass ash properties towards treatment and recycling. Renew. Sustain. Energy Rev. 2018, 96, 479-486. [CrossRef]

21. Stabile, P.; Bello, M.; Petrelli, M.; Paris, E.; Carroll, M.R. Carroll, Vitrification treatment of municipal solid waste bottom ash. Waste Manag. 2019, 95, 250-258. [CrossRef]

22. Rodger, B.; Bridgewater, A.L. Standard Methods for the Examination of Water and Wastewater; American Public Health Association: Washington, DC, USA, 2017.

23. Teixeira, E.R.; Camões, A.; Branco, F.G. Valorisation of wood fly ash on concrete. Resour. Conserv. Recycl. 2019, 145, 292-310. [CrossRef]

24. Bernardo, M.; Rodrigues, S.; Lapa, N.; Matos, I.; Lemos, F.; Batista, M.K.S.; Carvalho, A.P.; Fonseca, I. High efficacy on diclofenac removal by activated carbon produced from potato peel waste. Int. J. Environ. Sci. Technol. 2016, 13, 1989-2000. [CrossRef]

25. Das, B.; Hazarika, P.; Saikia, G.; Kalita, H.; Goswami, D.C.; Das, H.B.; Dube, S.N.; Dutta, R.K. Removal of iron from groundwater by ash: A systematic study of a traditional method. J. Hazard Mater. 2007, 141, 834-841. [CrossRef]

26. Adams, F.V.; Peter, A.; Joseph, I.V.; Sylvester, O.P.; Mulaba-Bafubiandi, A.F. Purification of crude oil contaminated water using fly ash/clay. J. Water Process. Eng. 2019, 30, 100471. [CrossRef]

27. Kalembkiewicz, J.; Galas, D.; Sitarz-Palczak, E. The Physicochemical Properties and Composition of Biomass Ash and Evaluating Directions of its Applications. Pol. J. Environ. Stud. 2018, 27, 2593-2603. [CrossRef]

28. Demeyer, A.; Nkana, J.V.; Verloo, M.G. Characteristics of wood ash and influence on soil properties and nutrient uptake: An overview. Bioresour. Technol. 2001, 77, 287-295. [CrossRef]

29. Zanzi, R.; Sjöström, K.; Björnbom, E. Rapid pyrolysis of agricultural residues at high temperature. Biomass Bioenergy 2002, 23, 357-366. [CrossRef]

30. Changmai, M.; Banerjee, P.; Nahar, K.; Purkait, M.K. A novel adsorbent from carrot, tomato and polyethylene terephthalate waste as a potential adsorbent for Co (II) from aqueous solution: Kinetic and equilibrium studies. J. Environ. Chem. Eng. 2018, 6, 246-257. [CrossRef]

31. Palma, C.; Contreras, E.; Urra, J.; Martínez, M.J. Eco-friendly technologies based on banana peel use for the decolourization of the dyeing process wastewater. Waste Biomass Valorization 2010, 2, 77-86. [CrossRef]

32. Masindi, V.; Osman, M.S.; Abu-Mahfouz, A.M. Integrated treatment of acid mine drainage using BOF slag, lime/soda ash and reverse osmosis (RO): Implication for the production of drinking water. Desalination 2017, 424, 45-52. [CrossRef]

33. Kadir, N.N.A.; Shahadat, M.; Ismail, S. Role of clay-based membrane for removal of copper from aqueous solution. Appl. Clay Sci. 2017, 137, 168-175. [CrossRef]

34. Wang, J.; Wang, S. Preparation, modification and environmental application of biochar: A review. J. Clean. Prod. 2019, 227, 1002-1022. [CrossRef]

35. Bhatnagar, A.; Sillanpää, M.; Witek-Krowiak, A. Agricultural waste peels as versatile biomass for water purification-A review. Chem. Eng. J. 2015, 270, 244-271. [CrossRef]

36. Nandiyanto, A.B.D.; Rahman, T.; Fadhlulloh, M.A.; Abdullah, A.G.; Hamidah, I.; Mulyanti, B. Working Volume in High-Energy Ball-Milling Process on Breakage Characteristics and Adsorption Performance of Rice Straw Ash. IOP Conf. Ser. Mater. Sci. Eng. 2016, 128. [CrossRef] 
37. Balogun, A.O.; Lasode, O.A.; Li, H.; McDonald, A.G. Fourier transform infrared (FTIR) study and thermal decomposition kinetics of sorghum bicolour glume and albizia pedicellaris residues. Waste Biomass Valorization 2014, 6, 109-116. [CrossRef]

38. Martinez, M.; Miralles, N.; Hidalgo, S.; Fiol, N.; Villaescusa, I.; Poch, J. Removal of lead (II) and cadmium (II) from aqueous solutions using grape stalk waste. J. Hazard Mater. 2006, 133, 203-211. [CrossRef]

39. Sepehr, M.; Mansur, Z.; Hossein, K.; Abdeltif, A.; Kamiar, Y.; Hamid, R.G. Potential of waste pumice and surface modified pumice for hexavalent chromium removal: Characterization, equilibrium, thermodynamic and kinetic study. Appl. Surf. Sci. 2013, 274, 295-305. [CrossRef]

40. Ates, A. The modification of aluminium content of natural zeolites with different composition. Powder Technol. 2019, 344, 199-207. [CrossRef]

41. Taha, G.M.; Arifien, A.E.; El-Nahas, S. Pomegranate (Punica graantum) Peels as an Agricultural Waste for Removing of CD(II), CR(VI), CU(II), NI(II), PB(II) and ZN(II) from Their Aqueous Solutions. Int. J. Glob. Health Health Disparities 2009, 6, 32-49.

42. Khaskheli, M.I.; Memon, S.Q.; Siyal, A.N.; Khuhawar, M.Y. Use of orange peel waste for arsenic remediation of drinking water. Waste Biomass Valorization 2011, 2, 423-433. [CrossRef]

43. Palacio, S.; Aitkenhead, M.; Escudero, A.; Montserrat-Marti, G.; Maestro, M.; Robertson, A.H. Gypsophile chemistry unveiled: Fourier transform infrared (FTIR) spectroscopy provides new insight into plant adaptations to gypsum soils. PLoS ONE 2014, 9, e107285.

44. Trivedi, N.S.; Kharkar, R.A.; Mandavgane, S.A. Utilization of cotton plant ash and char for removal of 2, 4-dichlorophenoxyacetic acid. Resour.-Effic. Technol. 2016, 2, S39-S46. [CrossRef]

45. Bruckman, V.J.; Wriessnig, K. Improved soil carbonate determination by FT-IR and X-ray analysis. Environ. Chem. Lett. 2013, 11, 65-70. [CrossRef]

46. Berzina-Cimdina, L.; Borodajenko, N. Chapter 6: Research of Calcium Phosphates Using Fourier Transform Infrared Spectroscopy. In Infrared Spectroscopy_Materials Science, Engineering and Technology; Theophile, P.T., Ed.; InTech: London, UK, $2012 ;$ p. 510.

47. Saikia, B.J.; Parthasarathy, G.; Sarmah, N.C. Fourier transform infrared spectroscopic estimation of crystallinity in $\mathrm{SiO}_{2}$ based rocks. Bull. Mater. Sci. 2008, 31, 775-779. [CrossRef]

48. Masindi, V.; Madzivire, G.; Tekere, M. Reclamation of water and the synthesis of gypsum and limestone from acid mine drainage treatment process using a combination of pre-treated magnesite nanosheets, lime, and $\mathrm{CO}_{2}$ bubbling. Water Resour. Ind. 2018, 20, 1-14. [CrossRef]

49. Pandey, V.C.; Abhilash, P.C.; Upadhyay, R.N.; Tewari, D.D. Application of fly ash on the growth performance and translocation of toxic heavy metals within Cajanus cajan L.: Implication for safe utilization of fly ash for agricultural production. J. Hazard Mater. 2009, 166, 255-259. [CrossRef] [PubMed]

50. Kefeni, K.K.; Mamba, B.B. Evaluation of charcoal ash nanoparticles pollutant removal capacity from acid mine drainage rich in iron and sulfate. J. Clean. Prod. 2020, 251, 119720. [CrossRef]

51. Masindi, V. Recovery of drinking water and valuable minerals from acid mine drainage using an integration of magnesite, lime, soda ash, $\mathrm{CO}_{2}$ and reverse osmosis treatment processes. J. Environ. Chem. Eng. 2017, 5, 3136-3142. [CrossRef]

52. Scholz, M. Wetlands for Water Pollution Control II Water Softening, 2nd ed.; Elsevier, B.V.: Amsterdam, The Netherlands, 2016; pp. 111-114.

53. Zhao, Y.; Cao, H.; Xie, Y.; Yuan, J.; Ji, Z.; Yan, Z. Mechanism studies of a CO2 participant softening pretreatment process for seawater desalination. Desalination 2016, 393, 166-173. [CrossRef]

54. Mohammadesmaeili, F.; Badr, M.K.; Abbaszadegan, M.; Fox, P. Mineral recovery from inland reverse osmosis concentrate using isothermal evaporation. Water Environ. Res. 2010, 82, 342-350. [CrossRef]

55. Luo, H.S.J.; Markström, H.; Wang, Z.; Niu, Q. Removal of $\mathrm{Cu}^{2+}$ from aqueous solution using fly ash. J. Miner. Mater. Charact. Eng. 2011, 10, 561-571.

56. Bora, A.J.; Dutta, R.K. Removal of metals ( $\mathrm{Pb}, \mathrm{Cd}, \mathrm{Cu}, \mathrm{Cr}, \mathrm{Ni}$, and $\mathrm{Co}$ ) from drinking water by oxidation-coagulation-absorption at optimized pH. J. Water Process. Eng. 2019, 31, 100839. [CrossRef]

57. O'Donnell, A.J.; Lytle, D.A.; Harmon, S.; Vu, K.; Chait, H.; Dionysiou, D.D. Capacitive deionization of a RO brackish water by AC/graphene composite electrodes. Water Res. 2016, 103, 319-333. [CrossRef]

58. Li, T.; Sui, F.; Li, F.; Cai, Y.; Jin, Z. Selective Environmental Remediation of Strontium and Cesium Using Sulfonated Hyper-CrossLinked Polymers (SHCPs). Powder Technol. 2014, 254, 338-343. [CrossRef]

59. Shu, L.; Obagbemi, I.J.; Liyanaarachchi, S.; Navaratna, D.; Parthasarathy, R.; Aim, R.B.; Jegatheesan, V. Why does pH increase with $\mathrm{CaCl}_{2}$ as draw solution during forward osmosis filtration. Process. Saf. Environ. Protection 2016, 104, 465-471. [CrossRef]

60. Twort, A.C.; Ratnayaka, D.D.; Brandt, M.J. Water Supply, 5th ed.; Butterworth-Heinemann Elsevier: Oxford, UK, 2000.

61. Iqbal, M.; Saeed, A.; Zafar, S.I. FTIR spectrophotometry, kinetics and adsorption isotherms modeling, ion exchange, and EDX analysis for understanding the mechanism of $\mathrm{Cd}^{2+}$ and $\mathrm{Pb}^{2+}$ removal by mango peel waste. J. Hazard. Mater. 2009, 164, 161-171. [CrossRef] [PubMed]

62. Kinnarinen, T.; Golmaei, M.; Jernström, E.; Häkkinen, A. Removal of hazardous trace elements from recovery boiler fly ash with an ash dissolution method. J. Clean. Prod. 2019, 209, 1264-1273. [CrossRef]

63. Samolada, M.C.; Zabaniotou, A.A. Energetic valorization of SRF in dedicated plants and cement kilns and guidelines for application in Greece and Cyprus. Resour. Conserv. Recycl. 2014, 83, 34-43. [CrossRef] 